\title{
Taxonomic revision of Myotis emarginatus: detailed morphometric analysis and final evaluation of the evidence (Chiroptera: Vespertilionidae)
}

\author{
Petr BENDA ${ }^{1,2}$ \& Marek UVIZL M $^{2,1}$ \\ ${ }^{1}$ Department of Zoology, National Museum (Natural History), Václavské nám. 68, \\ CZ-115 79 Praha 1, Czech Republic; petr.benda@nm.cz \\ ${ }^{2}$ Department of Zoology, Faculty of Science, Charles University in Prague, Viničná 7 , \\ CZ-128 44 Praha 2, Czech Republic
}

received on 14 November 2021

\begin{abstract}
The Geoffroy's bat, Myotis emarginatus, is the only species distributed in the Palaearctic belonging to the African clade of the genus Myotis. It occurs extensively across several ecologic zones of Europe, north-western Africa, and western and central Asia, and hence it was considered to be a polytypic species. Only one subspecies was reported from Europe and North Africa, up to four subspecies were recognised in Asia. However, the validity of particular taxa as well as the systematic positions of different populations remained ambiguous. Here we present a revision of the intraspecific phylogenetic structure of $M$. emarginatus based on combination of the available results of a molecular genetic analysis with the results of a thorough morphologic examination of an extensive specimen set from almost the whole range of its distribution. The previously described geographic variability in the mitochondrial markers demonstrated grouping of haplotypes of M. emarginatus into three main lineages that occur in (1) the Mediterranean Basin (including central Europe, the Maghreb and Levant), (2) Oman and south-eastern Iran, and (3) northern Iran and West Turkestan. The morphologic comparison uncovered the existence of four main, geographically exclusive morphotypes in M. emarginatus, concerning the body, skull and tooth sizes, and skull and tooth shapes: (1) rather small bats with short rostrum and high braincase, occurring in Europe and north-western Africa; (2) rather medium-sized bats with long rostrum and short braincase from the Levant including Cyprus; (3) large bats with wide and long rostrum from the south-eastern parts of the Middle East, including Oman, south-eastern Iran and eastern Afghanistan, and (4) large bats with narrow and short rostrum, occurring in Crimea, the Caucasus region, and West Turkestan. As a synthesis of the results of both approaches, we suggest to recognise three subspecies within the Myotis emarginatus species rank - M. e. emarginatus (Geoffroy, 1806) distributed in the Mediterranean, central and western Europe, north-western Africa, and in the Levant; M. e. desertorum (Dobson, 1875) in the south-eastern Middle East, including southern Iran, Oman, and Afghanistan; and M. e. turcomanicus Bobrinskoj, 1925 in the Caucasus region, Crimea, Transcaucasia, and West Turkestan.
\end{abstract}

Key words. Myotis emarginatus, morphology, morphometry, phylogenetics, taxonomy.

\section{INTRODUCTION}

The Geoffroy's bat, Myotis emarginatus (Geoffroy, 1806), is a bat with the Mediterranean type of distribution, occuring in the south-western part of the Palaearctic (CORBET 1978, KoOPMAN 1994, HorÁČEK et al. 2000). It represents the only species of the African clade of the genus Myotis (sometimes referred to the subgenus Chrysopteron Jentink, 1910), substantially distributed 
in the Palaearctic (Stadelmann et al. 2004, Ruedi et al. 2013, Morales et al. 2019). This bat occurs in the Maghreb from Morocco to Tunisia, in Europe from Portugal and the Netherlands through central and southern Europe to the Balkans, Crimea and Caucasus region, including some Mediterranean islands (TopéL 2001, DiETz et al. 2007); and discontinuously in Asia from the Levant, Asia Minor and Iraq to south-eastern Kazakhstan, southern Kirghizstan, and eastern Afghanistan (RYBIN et al. 1989, Habilov 1992, BENDA et al. 2006, 2012, BENDA \& GAISLER 2015, AL-SHEIKHLY et al. 2016). However, this species also almost reaches the Afro-tropical region in Arabia, its range continues patchily to north-eastern Oman and to western Saudi Arabia and Yemen (Harrison 1977, Gaucher 1995, Al-Jumaily 2003).

In this broad range (Fig. 1), stretching over a wide longitudinal belt across several ecologic and biogeographic zones, $M$. emaginatus was traditionally considered a polytypic species (OGNEV 1928, Ellerman \& Morrison-Scott 1951, Corbet 1978, Koopman 1994, HoráčeK et al. 2000, Topál 2001, Simmons 2005, Dietz et al. 2007). Up to four subspecies have been recognised; viz. M. e. emarginatus (Geoffroy, 1806) in the Mediterranean Basin and adjacent areas of Europe, the Maghreb and Levant (terra typica [t.t.]: Charlemont [Givet, Champagne-Ardenne, France]; GeofFroy-SAINT-Hilaire 1806: 198); M. e. desertorum (Dobson in Blanford, 1875) in the south-eastern part of the Middle East (t.t.: Jálk, Balúchistán [Iran]; BLANFORD 1875: 309); M. e. turcomanicus Bobrinskoj, 1925 in the western part of West Turkestan (t.t.: Moorghab [= Murgab] River Valley, Turkmen-Kala, West Turkestan [Turkmenistan]; BoBRInsKoJ 1925: 359); and M. e. kuzyakini Rossolimo et Pavlinov, 1979 in the eastern part of West Turkestan (t.t.: Taškent [Uzbekistan]; KuZÂKIN 1934: 320). However, the opinions on geographic variation in this bat are based mostly on the comparisons of colour morphs and/or of metric data of an insufficient number of specimens (see TopáL 2001).

Despite this relatively simple geographic division, the history of the intraspecific taxonomic classification of $M$. emarginatus is not straightforward. While the opinions concerning the taxonomic arrangement of the Mediterranean and European populations of this bat are rather consistent and assign these populations more or less constantly to the nominotypical subspecies (see e.g. Ognev 1928, Ellerman \& Morrison-Scott 1951, Harrison 1964, Corbet 1978, Gaisler 1983, Harrison \& Bates 1991, Kowalski \& RzebiK-Kowalska 1991, Koopman 1994, HoráČEK et al. 2000, Topál 2001, Karataş \& ÖzgüL 2003, AlbaYraK 2015, etc.), the opinions on the subspecific variation within the Asian part of the species range are more intricate. Considering the latter populations, four names have been created in the rank of M. emarginatus, while only one of them was synonymised early after its description.

The name M. lanaceus (t.t.: Shastun, Dizak, Baluchistan [Iran]; THOMAs 1920: 933), originally created as lanceus and corrected to the current form by WROUGHTON (1920), is now considered to be a junior synonym of the name Vespertilio desertorum Dobson, 1875 as these names were described from the sites within a distance of only $50 \mathrm{~km}$ and the colouration and body size of the representatives are reported to be almost identical (OGNEV 1928, ELLERMAN \& MORRISONScotT 1951, DeBlase 1980).

The taxon desertorum was originally considered to be a separate species distributed from eastern Transcaucasia to Central Asia and Iran (DobSON 1878, SATUNIN 1896, 1914, Bianki 1917, Thomas 1920). On the other hand, Bobrinskoj (1925) and OGNev (1927) regarded the West Turkestani populations of M. emarginatus to belong to M. e. turcomanicus, differing from the nominotypical and Iranian forms by ear morphology and pelage colouration. However, OGNEFF \& HEPTNER (1928) and OGNEV (1928) very early synonymised the latter name with M.e. desertorum, which they considered to occur in West Turkestan and Iran, and besides that, they 


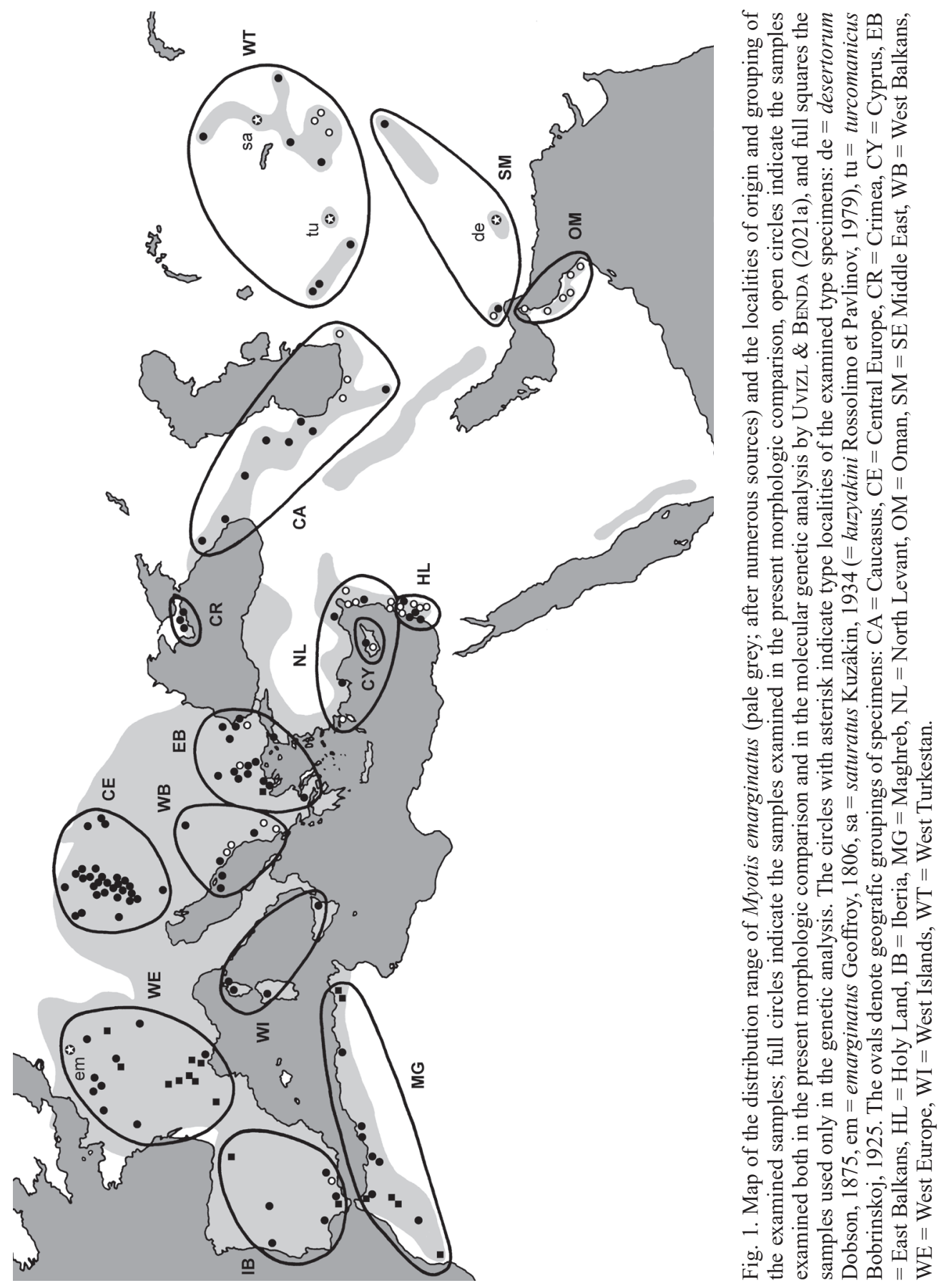


recognised only M. e. emarginatus within the remaining species range (Crimea, Transcaucasia, Europe, North Africa). However, KuZÂKIN $(1934,1935)$ defined a third Asian subspecies from the eastern part of West Turkestan, M. e. saturatus Kuzâkin, 1934 [nec M. yumanensis saturatus Miller, 1897; replaced with M. e. kuzyakini as a nomen novum, see Rossolimo \& PAVLINOv 1979: 13], being darker coloured than other Asian taxa, while he regarded the form turcomanicus just a synonym of M. e. desertorum, following OGNEV (1928).

ELLERMAN \& MORRISON-SCOTT (1951) suggested all three Asian forms as valid subspecies, desertorum, turcomanicus, and saturatus [= kuzyakini], besides the nominotypical subspecies. STRELKov (1963) distinguished only two subspecies within the area of the former Soviet Union, the darker M. e. emarginatus in Europe and the Caucasus region, and the paler M. e. desertorum in West Turkestan. Since the latter name is the prior synonym in the non-European part of the distribution range, STRELKOv's (1963) taxonomic division applies to the whole species range (perhaps with the exceptions of North Africa and the Levant). Afterwards, KuZÂKIN (1965) and STRELKOV (1981) presented a three subspecies concept in M. emarginatus in its former Soviet range; it comprised a relatively dark and small-sized M. e. emarginatus in Europe, North Africa, Crimea, and Transcaucasia, a relatively pale and small-sized M.e.desertorum in the deserts of Iran and southern Turkmenistan, and a relatively dark and large M. e. saturatus $[=$ kuzyakini] in eastern West Turkestan. CORBET (1978) adopted this conception for the whole range of the species, i.e. he assigned also the populations of North Africa to M. e. emarginatus along with those of Europe, but the status of the Levantine bats remained unspecified.

DeBlase (1980) determined even two to three colour forms in the territory of Iran and coidentified them with separate subspecies; he restricted the pale $M$. e. desertorum to southeastern Iran only; in southwestern, western and northern parts of the country he found the dark M. $e$. emarginatus, and a possible third unnamed form with a very reddish pelage in the Caspian region. Additionally, HARRISON \& BATES (1991), who first evaluated M. emarginatus samples from Oman, identified these bats as $M$. e. desertorum.

As a result, KoOpMan (1994) summarised the intraspecific taxonomy of $M$. emarginatus with four subspecies, M. e. emarginatus in Europe, northwestern Africa and south-western Asia, $M$. e. desertorum in Oman to Afghanistan, M. e. turcomanicus in Turkmenistan to Afghanistan [!], and M. e. saturatus [= kuzyakini] in Uzbekistan. HorÁČEK et al. (2000) adopted this arrangement, although they did not specify distribution of the particular subspecies. On the other hand, Simmons (2005) recognised only three subspecies in M. emarginatus, i.e. the above-mentioned content by KoOPMAN (1994) except kuzyakini, and considered the Uzbekistani populations a part of the nominotypical form from Europe.

These opinions could be summarised as follows; the authors who evaluated only individual samples or small sample series of $M$. emarginatus reported significant differences in the pelage colouration and the different colour morphs assigned to separate taxa, while the authors who evaluated large sets of $M$. emarginatus from different types of habitats, found a mosaic of colouration morphs (see also TopÁL 2001). Therefore, BENDA et al. (2006) who compared a large set of specimens from most parts of the species range, suggested the intensity of colourations tinges to be most probably linked to humidity level of the particular habitat; the pale individuals were reported to occur in the lowland semi-arid regions of West Turkestan and Iran, while individuals found in the arboreal habitats of the Mediterranean (including parts of western Asia) were dark reddish- or orange-brown coloured. Thus, they concluded that the pelage colouration represents a varying character adaptive to the local environment conditions with a low or no reflection in the phylogenetic relations within the species as a whole. 
Additionally, BENDA et al. (2006) were the only who tried to evaluate the geographic variation in M. emarginatus with the help of a morphometric analysis of a large set of museum specimens. Their results showed three basic groups of size morphotypes within the species distribution range, which were referred by these authors to two subspecies. The large-sized morphotype contained all the populations of the eastern parts of the species range (Crimea, Caucasus, Iran, Afghanistan, West Turkestan) and was identified under the prior name originating from the region, M. e. desertorum. The other two morphotypes, the small-sized morphotype of populations from south-western and central Europe and the northern part of the Balkans as well as the medium-sized morphotype originating from two separate regions, the Maghreb and eastern Mediterranean (southern Balkans to the Levant), were considered to represent the nominotypical subspecies. This view of two subspecies in $M$. emarginatus has been recently adopted by LóPEZ-BAUCELLS (2019).

Several initial molecular genetic analyses of the mitochondrial sequences of $M$. emarginatus (IBÁÑEZ et al. 2006, MAYER et al. 2007, GARCÍA-MUdARRA et al. 2009) covered only the Mediterranean Basin and Central Europe. The samples from Morocco, Iberia, Belgium, Germany, Greece, and Israel formed a single clade with very low divergences - according to indirect indications by the respective authors, about less than $1 \%$ of genetic distances. This was in concert with

A

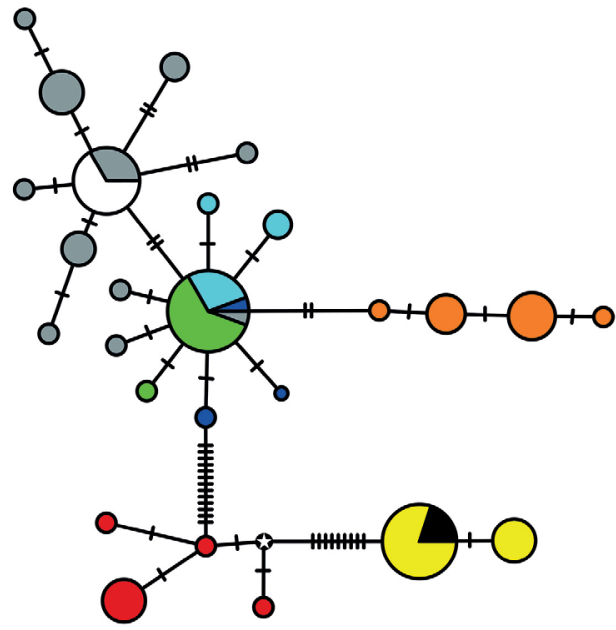

I

Maghreb
West Europe
Balkans
North Levant

Cyprus
Holy Land
B

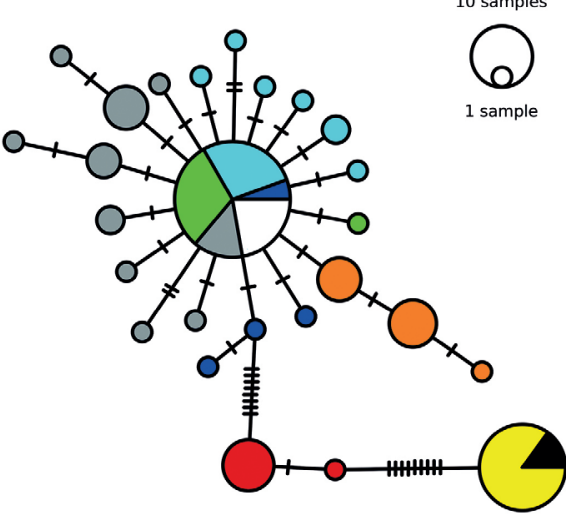

II

Oman
South Iran

III

North Iran

West Turkestan

Fig. 2. Median haplotype networks computed from sequences of the mitochondrial gene for cytochrome $b$ of Myotis emarginatus (after UvizL \& BENDA 2021a, slightly modified); A - a network from the sequences of length $1024 \mathrm{bp}(\mathrm{n}=93), \mathrm{B}$ - a network from the sequences of length $703 \mathrm{bp}(\mathrm{n}=104)$. Coloured circles and circle sectors represent different geographic populations. Black circle with a white star represents hypothetical haplotype connecting those represented by samples, hatch marks denote base pair substitutions. 
the traditional opinions that the Mediterranean Basin and Central Europe are inhabited by only one taxon, i.e. the nominotypical subspecies (see above). Neverthelles, the systematic position of the remaining populations of $M$. emarginatus remained unclear and the same applied to the mutual relations of the Euro-Mediterranean and Asian populations of this bat.

As a next step, we performed a thorough molecular genetic analysis of more than a hundred of samples of $M$. emarginatus from most of its distribution range, from Morocco and France to Oman and Tajikistan (see Fig. 1), using both mitochondrial and nuclear markers (UvIZL $\&$ BENDA 2021a). While the results of analysis of the mitochondrial genome (D-loop of the control region and the cytochrome $b$ gene) revealed existence of three haplotype groups (Fig. 2), the nuclear markers (recombination activating gene 2, acyl-coenzyme A oxidase 2 intron, and signal transducer and activator of transcription 5A intron) did not show any inner arrangement of the haplotypes and all sequences belonged to one well supported common lineage. The geographic arrangement of the mitochondrial haplogroups corresponded with three regions, (1) Europe and the Mediterranean Basin, (2) Oman and south-eastern Iran, and (3) northern Iran and West Turkestan; the Euro-Mediterranean lineage was again diversified into three sublineages, Euro-Maghrebian, North Levantine, and South Levantine (Holy Land), see Fig. 2. The interpretation of these results followed the preliminary results of the morphometric analysis by BENDA et al. (2006) and suggested to accept two basic phylogroups within the species, the western and eastern ones, corresponding with two subspecies sensu BENDA et al. (2006), M. e. emarginatus in the west and M. e. desertorum in the east of the species range.

However, these conclusions were based on a morphologic comparison that used only a geographically limited set of samples (some 320 specimens) and mainly, only a basic set of analysed variables (12 craniodental dimensions). Therefore, the intraspecific status of particular populations of $M$. emarginatus in the whole species cannot be considered resolved. The results of the profound molecular genetic analyses must be interpreted in the light of results of a profound morphologic analysis. Thus, we conducted a fine morphologic examination of a set of almost five hundred specimens from Europe, North Africa, Middle East, Caucasus region and West Turkestan, i.e. from all parts of the distribution range of this bat (except for south-western Arabia; see Fig. 1).

The results of this morphologic analysis along with the results of the molecular genetic analysis (UVIZL \& BENDA 2021a) enabled us to make a sufficiently supported synthesis of the intraspecific arrangement of $M$. emarginatus, and its taxonomic formulation.

\section{MATERIAL AND METHODS}

\section{An a ly s is}

In the morphologic analysis, museum material of more than 460 specimens of Myotis emarginatus from the majority of its distribution range was used, see Fig. 1 and Appendix for the origin of the specimens examined. Primarily cranial and dental data were used for the analyses, see Abbreviations and terminology for the dimensions taken. In the comparison, the type material of the names emarginatus Geoffroy, 1806, desertorum Dobson, 1875, turcomanicus Bobrinskoj, 1925, and saturatus Kuzâkin, 1934, was evaluated.

The specimens were measured in a standard way using mechanical or optical calipers. Statistical analyses were performed using the Statistica 6.0 software. We performed also a stepwise discriminant function analysis as a test of an importance of particular dimensions for the intraspecific variation. Statistically significant parameters most affecting the morphologic variation were selected and employed in a subsequent canonical analysis. 


\section{Abbreviations and terminology}

Dimensions. $\mathrm{LAt}=$ forearm length (incl. wrist) $-\mathrm{LCr}=$ greatest length of skull; $-\mathrm{LCb}=$ condylobasal length; $-\mathrm{LaZ}=$ zygomatic width; $-\mathrm{LaI}=$ width of interorbital constriction; $-\mathrm{LaInf}=$ rostral width between infraorbital foramens; $-\mathrm{LaN}=$ neurocranium width; $-\mathrm{ANc}=$ neurocranium height $;-\mathrm{CC}=$ rostral width between upper canines (incl.); $-\mathrm{M}^{3} \mathrm{M}^{3}=$ rostral width between 3 rd upper molars (incl.); $-\mathrm{CM}^{3}=$ length of upper tooth-row between canine and 3 rd molar (incl.); $-\mathrm{CP}^{4}=$ length of upper tooth-row between canine and 3 rd premolar (incl.); $-\mathrm{P}^{2} \mathrm{P}^{3}=$ length of upper tooth-row between 1 st and 2 nd premolars (incl.); - $\mathrm{LP}^{3}$ $=$ mesio-distal crown length of upper 2 nd premolar $\left(\mathrm{P}^{3}\right) ;-\mathrm{LP}^{4}=$ mesio-distal crown length of upper 3rd premolar $\left(\mathrm{P}^{4}\right) ;-\mathrm{LaP}^{4}=$ palato-labial crown width of upper 3 rd premolar $\left(\mathrm{P}^{4}\right) ;-\mathrm{M}^{1} \mathrm{M}^{3}=$ length of upper molar-row (incl.); $-\mathrm{LaM}^{1}=$ palato-labial crown width of upper 1 st molar; $-\mathrm{LaM}^{2}=$ palato-labial crown width of upper 2nd molar; $-\mathrm{LaM}^{3}=$ palato-labial crown width of upper 3rd molar; $-\mathrm{LMd}=$ condylar length of mandible; $-\mathrm{ACo}=$ height of coronoid process; $-\mathrm{CM}_{3}=$ length of lower tooth-row between canine and 3rd molar (incl.).

Collections. BMNH = Natural History Museum, London, United Kingdom; - EBD = Doñana Biological Station, Seville, Spain; - ISEA = Institute of Systematics and Evolution of Animals, Polish Academy of Sciences, Cracow, Poland; - IVB = Institute of Vertebrate Biology, Academy of Sciences of the Czech Republic, Brno, Czech Republic; - JOC = Ján Obuch Collection, Blažovce, Slovakia; - MHNG = Natural History Museum, Geneva, Switzerland; - MNHN = National Museum of Natural History, Paris, France; - MSNG = Civil Museum of Natural History Giacomo Doria, Genoa, Italy; - MUB = Department of Zoology, Masaryk University, Brno, Czech Republic; - NMP = National Museum (Natural History), Prague, Czech Republic; - NMW = Natural History Museum, Vienna, Austria; - SMF = Research Institute and Museum Senckenberg, Frankfurt am Main, Germany; - TAU = Tel Aviv University, Tel Aviv, Israel; - VMO = Regional Museum, Olomouc, Czech Republic; - ZFMK = Zoological Institute and Museum Alexander Koenig, Bonn, Germany; - ZIN = Zoological Institute, Russian Academy of Sciences, St. Petersburg, Russia; - ZMH = Zoological Museum, University of Hamburg, Hamburg, Germany; - ZMMU = Zoological Museum of the Moscow State University, Moscow, Russia; - ZZZ = Zoological Collection, Faculty of Science, University of Zagreb, Zagreb, Croatia.

OTHER ABBreviations. $\mathrm{A}=$ alcoholic specimen; $-\mathrm{B}=\operatorname{skin}(\mathrm{balg}) ;-q=$ female $;-\hat{\delta}=$ male $;-\mathrm{M}=$ mean; $-\max , \min =$ range margins; $-\mathrm{S}=$ skull $;-\mathrm{SD}=$ standard deviation $;-\mathrm{Sk}=$ skeleton .

GEOGRAPHIC TERMS (considering origin of the examined material; in parentheses acronyms used in text and Fig. 1): Balkans (BA) = West Balkans plus East Balkans (WB+EB); - Caucasus $(\mathrm{CA})=$ Azerbaijan, northern Iran, Georgia, and Russian Caucasus; - Central Europe (CE) = Austria, northern Croatia, Czech Republic, and Slovakia; - Crimea $(\mathrm{CR})=$ Crimea (Ukraine); - East Balkans $(\mathrm{EB})=$ Bulgaria, Greece, and Turkish Thrace; - Holy Land (HL) = Israel, Jordan, and southern Lebanon; - Iberia (IB) = Portugal and Spain; - Levant $=$ North Levant plus Holy Land $(\mathrm{NL}+\mathrm{HL}) ;-$ Maghreb $(\mathrm{MG})=$ Algeria, Morocco, and Tunisia; North Levant $(\mathrm{NL})=$ Greek Dodecaneses, northern Lebanon, Syria, and southern Turkey; - Oman (OM) $=$ Oman; - SE Middle East $(\mathrm{SM})=$ Afghanistan and south-eastern Iran; - West Balkans $(\mathrm{WB})=$ Albania, southern Croatia, Montenegro, and Serbia; - West Europe (WE) = France and Switzerland; - West-Central Europe $(\mathrm{WCE})=$ Iberia, West Europe, West Islands, plus Central Europe (IB+WE+WI+CE); - West Islands $(\mathrm{WI})=$ Corsica, Sardinia, and Sicily; - West Turkestan $(\mathrm{WT})=$ north-eastern Iran, Kazakhstan, Kirghizstan, Tajikistan, Turkmenistan, and Uzbekistan.

\section{RESULTS}

The comparison of morphometric characters of particular population sets of Myotis emarginatus samples documented an extreme variation in body, skull, and tooth sizes as well as in skull and tooth shapes. In most dimensions, both in their absolute and relative values, the ranges found in the most numerous sets $(n>25)$ overlapped with or exceeded the ranges of the less numerous sets. However, metric trends in the particular population sample sets were well 
Table 1. Morphometric data on the examined sets of specimens. For the geographic delimitations of particular sets see Fig. 1, for dimension abbreviations see Abbreviations and terminology; PC dim = PCA results computed from skull dimensions, $\mathrm{PC}$ ind $=$ PCA results from skull indices

\begin{tabular}{|c|c|c|c|c|c|c|c|c|c|c|c|c|c|c|c|}
\hline \multirow[t]{2}{*}{ variable } & \multicolumn{5}{|c|}{ Maghreb (MG) } & \multicolumn{5}{|c|}{ Iberia (IB) } & \multicolumn{5}{|c|}{ West Islands (WI) } \\
\hline & $\mathrm{n}$ & M & $\min$ & $\max$ & SD & $\mathrm{n}$ & $\mathbf{M}$ & $\min$ & $\max$ & SD & $\mathrm{n}$ & M & $\min$ & $\max$ & SD \\
\hline LAt & 9 & 40.34 & 38.6 & 42.6 & 1.482 & 7 & 39.03 & 37.8 & 40.5 & 1.044 & 12 & 39.54 & 37.1 & 41.4 & 1.105 \\
\hline $\mathrm{Cr}$ & 15 & 15.78 & 15.12 & 16.47 & 0.349 & 11 & 15.71 & 15.22 & 16.45 & & 12 & 15.51 & 15.02 & 15.92 & 0.254 \\
\hline $\mathrm{Cb}$ & 15 & 14.83 & 14.17 & 15.57 & & 11 & & & & & 12 & & & 14.97 & 0.298 \\
\hline $\mathrm{aZ}$ & 15 & 9.88 & 9.57 & 10.18 & & 11 & 9.76 & & 10.20 & & 8 & & 9.12 & 10.02 & 0.274 \\
\hline LaI & 15 & 3.58 & 3.45 & 3.73 & & 11 & 3.50 & & & & 12 & 3.47 & 32 & 3.63 & 0.105 \\
\hline LaInf & 15 & 3.84 & 3.6 & 4.00 & & 12 & 3.73 & & & & 12 & & 47 & & 0.149 \\
\hline $\mathrm{aN}$ & 15 & 7.42 & 7.2 & 7.60 & & 12 & 7.27 & & & & & & & & 0.092 \\
\hline $\mathrm{Nc}$ & 15 & 5.87 & 5.5 & 6.14 & & 2 & 5.81 & & & & & 5.72 & & 5.98 & 0.127 \\
\hline $\mathrm{C}$ & 15 & 4.03 & 3.8 & 4.22 & & 10 & 3.88 & & & & & & 57 & 4.18 & 0.198 \\
\hline $1^{3} \mathrm{M}^{3}$ & 15 & & & 6.47 & & 12 & 6.00 & & & & 12 & 6.05 & 67 & & 0.209 \\
\hline 3 & 1 & & & & & & & & & & & 24 & & & 148 \\
\hline & 15 & & & & & 11 & & & & & & & & & 087 \\
\hline $\mathrm{P}^{2} \mathrm{P}^{3}$ & 15 & 1.03 & 0.9 & & & 11 & & & & & & 08 & & & 035 \\
\hline $\mathrm{LP}^{3}$ & 9 & & & & & & & & & & & 51 & & & 023 \\
\hline & 15 & & & & & & & & & & & 1.24 & & & 060 \\
\hline & 1 & & & & & & & & & & & 1.36 & & & 045 \\
\hline & 15 & & & & & & & & & & & 3.48 & & 63 & 100 \\
\hline & 9 & & & & & & & & & & & 55 & & & 057 \\
\hline & 9 & & & & & & & & & & & 1.80 & & & \\
\hline & 9 & & & & & & & & & & & 1.74 & & & 60 \\
\hline & 15 & & & & & 11 & & & & & & .46 & & & 243 \\
\hline & 15 & & & & & 1 & & & & & & 37 & & & 112 \\
\hline $\mathrm{CM}_{3}$ & 15 & 6.74 & 6.44 & 6.97 & 0.145 & 11 & 6.66 & 6.42 & 6.88 & 0.150 & 12 & 6.66 & 6.23 & 6.95 & 0.204 \\
\hline $\mathrm{CC} / \mathrm{CM}^{3}$ & 15 & 0.637 & 0.605 & 0.663 & 0.018 & 10 & 0.616 & 0.584 & 0.654 & 0.041 & 11 & 0.626 & 0.597 & 0.663 & $\overline{0.021}$ \\
\hline $\mathrm{CM}^{3} / \mathrm{LCr}$ & 15 & 0.400 & 0.383 & 0.408 & 0.00 & 10 & 0.399 & 0.387 & 0.407 & & 12 & 0.402 & 0.390 & 0.412 & 0.006 \\
\hline $\mathrm{LaInf} / \mathrm{LCr}$ & 15 & 0.244 & 0.238 & 0.250 & 0.004 & 11 & 0.237 & 0.219 & 0.255 & 0.010 & 12 & 0.242 & 0.230 & 0.255 & 0.008 \\
\hline $\mathrm{LaN} / \mathrm{LCr}$ & 15 & 0.470 & 0.456 & 0.483 & 0.008 & 11 & 0.463 & 0.452 & 0.489 & 0.0 & 12 & 0.465 & 0.458 & 0.478 & 0.007 \\
\hline $\mathrm{ANc} / \mathrm{LaN}$ & 15 & 0.791 & 0.772 & 0.811 & 0.013 & 12 & 0.798 & 0.766 & 0.830 & 0.0 & 12 & 0.793 & 0.765 & 0.822 & 0.017 \\
\hline $\mathrm{ANc} / \mathrm{LCr}$ & 15 & 0.372 & 0.359 & 0.389 & 0.009 & 11 & 0.371 & 0.353 & 0.380 & 0.009 & 12 & 0.369 & 0.360 & 0.378 & 0.006 \\
\hline $\mathrm{P}^{2} \mathrm{P}^{3} / \mathrm{LCr}$ & 15 & 0.065 & 0.057 & 0.070 & 0.004 & 11 & 0.068 & 0.064 & 0.075 & 0.003 & 11 & 0.070 & 0.065 & 0.073 & 0.003 \\
\hline $\mathrm{P}^{2} \mathrm{P}^{3} / \mathrm{CM}^{3}$ & 15 & 0.162 & 0.147 & 0.176 & 0.008 & 11 & 0.169 & 0.158 & 0.184 & 0.008 & 11 & 0.173 & 0.161 & 0.188 & 0.009 \\
\hline $\mathrm{LP}^{3} / \mathrm{P}^{2} \mathrm{P}^{3}$ & 9 & 0.445 & 0.400 & 0.478 & 0.028 & 11 & 0.468 & 0.436 & 0.485 & 0.016 & 11 & 0.475 & 0.434 & 0.505 & 0.021 \\
\hline $\mathrm{LaM}^{3} / \mathrm{M}^{1} \mathrm{M}^{3}$ & 39 & 0.485 & 0.436 & 0.511 & 0.024 & 12 & 0.494 & 0.460 & 0.522 & & 12 & 0.501 & 0.484 & 0.521 & 0.010 \\
\hline $\mathrm{LaM}^{3} / \mathrm{LaM}^{1}$ & 9 & 1.096 & 0.994 & 1.152 & 0.047 & 12 & 1.104 & 1.061 & 1.152 & 0.0 & 12 & 1.124 & 1.065 & 1.181 & 0.034 \\
\hline & 15 & 0.295 & -0.990 & 1.779 & 0.73 & 12 & 0.576 & -0.568 & 1.969 & & 12 & 0.678 & -0.102 & 2.531 & 0.766 \\
\hline & 15 & -0.68 & & 0.370 & 0.640 & 12 & $0.168-$ & -0.985 & 1.656 & 0.8 & 12 & 0.363 & & 1.142 & 0.557 \\
\hline & 15 & & & & & 12 & & & 2.002 & & 12. & -0.106 & & & 0.418 \\
\hline $\mathrm{PC} 2$ ind & 15 & -0.240 & -1.644 & 0.896 & 0.629 & 12 & 0.405 - & -0.696 & 1.127 & 0.531 & 12 & 0.605 & -0.530 & 2.107 & 0.771 \\
\hline
\end{tabular}

$\rightarrow$

Fig. 3. Univariate plots of compared samples of Myotis emarginatus (bold horizontal lines = medians, boxes $=$ upper and lower quartiles, lines = ranges); examples of the plain dimensions. 


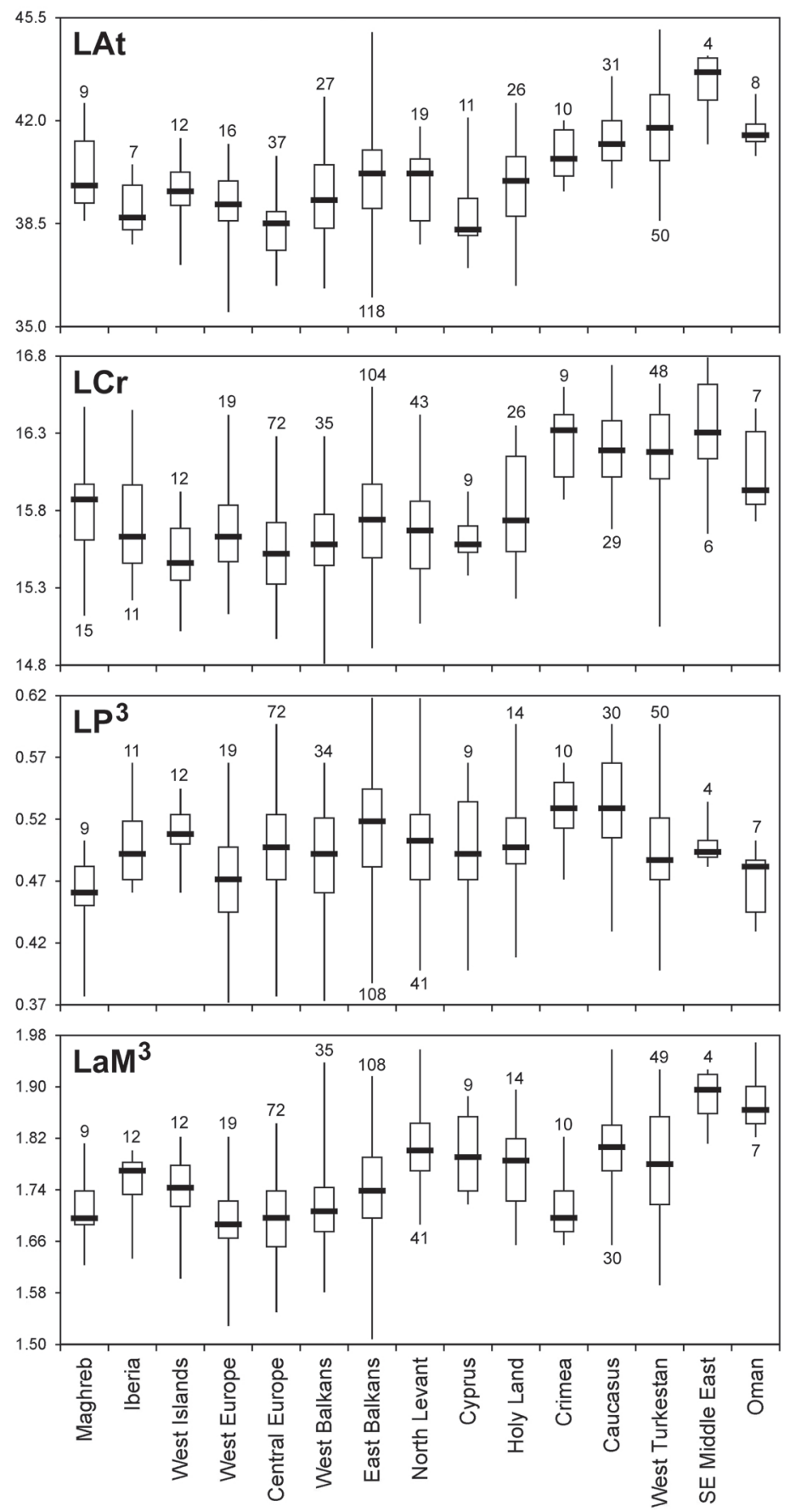


detectable from the comparison of the basic statistical values (mean/median, upper and lower quartiles; Figs. 3, 4, Table 1). The metric characters clustered the population sets into several groups; particular characters, such as body and skull size, rostrum and braincase shape, size of teeth, were compared separately (the ranges in parentheses below are delimited by the lower and upper quartile values, respectively, giving the best picture of the metric trend of a set within the whole species variation).

Based on the body and skull plain dimensions, best characterised by the forearm length (LAt) and largest length of skull (LCr), four size categories could be separated among $M$. emarginatus sample sets, see Fig. 3 and Table 1. The smallest body and skull dimensions were typical for the samples from West-Central Europe (IB+WE+WI+CE; LAt 37.6-40.3 mm; LCr 15.3-16.0 mm) and from Cyprus (LAt 38.1-39.4 mm; LCr 15.5-15.7 mm); medium-sized bodies and skulls were typical for the samples from the Maghreb (LAt 39.2-41.3 mm; LCr 15.6-16.0 mm), Balkans (WB+EB; LAt 38.3-41.0 mm; LCr 15.4-16.0 mm), and Levant (LAt 38.7-40.8 mm; LCr 15.4-16.2 mm); medium-sized bodies but large skulls were found in bats from Crimea (LAt 40.1-41.7 mm; LCr 16.0-16.5 mm) and the Caucasus (LAt 40.6-42.0 mm; LCr 16.0-16.4 mm); and large body and skull dimensions were typical for bats from West Turkestan (LAt 40.6-42.9 mm; LCr 16.0-16.5 mm), SE Middle East (LAt 42.7-44.1 mm; LCr 16.1-16.7 mm), and from Oman (LAt 41.3-41.9 mm; LCr 15.8-16.4 mm).

The absolute length of rostrum in $M$. emarginatus conformed with the overall skull size in a prevailing number of the sample sets. The only exception was found in the small-sized bats from Cyprus where the length of rostrum is slightly bigger than a value equal to the skull length. However, six categories appeared when the shape of rostrum was evaluated, i.e. its relative length and relative width (see Fig. 4). The most common category was the relatively medium-long and relatively narrow rostrum; such shape was found in the samples from the Maghreb $\left(\mathrm{CM}^{3} / \mathrm{LCr} 0.398-0.404\right.$; LaInf/LCr 0.240-0.247), Balkans $\left(\mathrm{CM}^{3} / \mathrm{LCr} 0.396-0.408 ; \mathrm{LaInf} / \mathrm{LCr}\right.$ 0.236-0.251), Crimea ( $\mathrm{CM}^{3} / \mathrm{LCr} 0.404-0.408$; LaInf/LCr 0.238-0.247), Caucasus $\left(\mathrm{CM}^{3} / \mathrm{LCr}\right.$ 0.399-0.406; LaInf/LCr 0.238-0.249), and West Turkestan (CM 3 /LCr 0.399-0.408; LaInf/ LCr 0.236-0.252). In the samples from the Levant, the rostrum was relatively medium-long to long but narrow $\left(\mathrm{CM}^{3} / \mathrm{LCr} 0.403-0.412\right.$; LaInf/LCr 0.236-0.248), while in the Cypriot bats the rostrum was relatively medium-long to long but wide $\left(\mathrm{CM}^{3} / \mathrm{LCr} 0.403-0.410\right.$; LaInf/LCr $0.245-$ 0.254). The bats from West-Central Europe had a relatively short and narrow rostrum $\left(\mathrm{CM}^{3} /\right.$ LCr 0.392-0.405; LaInf/LCr 0.235-0.249). The large bats from the SE Middle East and Oman showed a relatively very long rostrum, but while in the Omani bats it was relatively medium-wide to narrow $\left(\mathrm{CM}^{3} / \mathrm{LCr} 0.412-0.415\right.$; LaInf/LCr 0.239-0.250), in the SE Middle Eastern samples the rostrum was relatively wide $\left(\mathrm{CM}^{3} / \mathrm{LCr} 0.410-0.414\right.$; LaInf/LCr 0.243-0.258).

The shape of braincase showed extreme variability among the compared sample sets of $M$. emarginatus; eight shape types could be defined among the compared sample sets (Fig. 4). A relatively wide and high braincase was found in the bats from the Maghreb (LaN/LCr 0.464-0.474; ANc/LCr 0.366-0.376) and Balkans (LaN/LCr 0.461-0.477; ANc/LCr 0.360$0.377)$, while a relatively wide and low braincase in the Cypriot bats ( $\mathrm{LaN} / \mathrm{LCr} 0.466-0.475$; $\mathrm{ANc} / \mathrm{LCr}$ 0.354-0.368). A relatively medium-wide and high braincase was documented in the West-Central European bats (LaN/LCr 0.454-0.476; ANc/LCr 0.364-0.378), while a relatively medium-wide and low braincase in the bats from West Turkestan (LaN/LCr 0.454-0.470; ANc/ LCr $0.352-0.362)$. A relatively medium-wide and medium-high braincase were shown by the samples from the Levant (LaN/LCr 0.458-0.475; ANc/LCr 0.355-0.370) and Caucasus (LaN/ LCr $0.457-0.468 ;$ ANc/LCr $0.358-0.367)$. A relatively narrow and high braincase was found in 
Table 1. (continued)

\begin{tabular}{|c|c|c|c|c|c|c|c|c|c|c|c|c|c|c|c|}
\hline \multirow[t]{2}{*}{ variable } & \multicolumn{5}{|c|}{ West Europe (WE) } & \multicolumn{5}{|c|}{ Central Europe (CE) } & \multicolumn{5}{|c|}{ West Balkans (WB) } \\
\hline & $\mathrm{n}$ & M & $\min$ & $\max$ & SD & $\mathrm{n}$ & M & $\min$ & $\max$ & SD & $\mathrm{n}$ & M & $\min$ & $\max$ & SD \\
\hline LAt & 16 & 39.00 & 35.5 & 41.2 & 1.554 & 37 & 38.32 & 36.4 & 40.8 & 1.160 & 27 & 39.41 & 36.3 & 42.8 & 1.465 \\
\hline $\mathrm{Cr}$ & 19 & 5.72 & 15.13 & 16.42 & 0.375 & 72 & 15.52 & 14.97 & 16.28 & 0.274 & 35 & 15.57 & 4.81 & 16.28 & 0.344 \\
\hline $\mathrm{Cb}$ & 19 & 14.78 & 14.27 & 15.38 & & 69 & 14.63 & 13.83 & 15.51 & 306 & 35 & 14.64 & 13.75 & 5.34 & 322 \\
\hline $\mathrm{aZ}$ & 15 & 9.77 & 9.53 & 10.07 & 169 & 67 & 9.57 & 8.87 & 10.31 & 231 & 34 & 9.65 & 8.72 & 10.19 & 0.273 \\
\hline aI & 19 & 3.63 & 3.42 & 3.79 & 0.109 & 72 & 3.52 & 3.17 & 3.85 & 124 & 35 & 3.51 & .26 & 3.93 & 0.127 \\
\hline $\operatorname{Inf}$ & 19 & 3.83 & 3.65 & 4.08 & 0.102 & 72 & 3.71 & 3.43 & 4.02 & & 5 & 3.77 & .47 & 4.12 & 0.169 \\
\hline $\mathrm{IN}$ & 19 & 7.39 & 7.13 & 7.67 & 141 & 72 & 7.32 & 6.94 & 91 & & 5 & 7.32 & 91 & 7.93 & 0.216 \\
\hline $\mathrm{Nc}$ & 19 & 5.86 & 5.71 & 6.06 & 106 & 72 & 5.70 & 5.36 & 98 & & 5 & 78 & 37 & 6.12 & 0.161 \\
\hline & 19 & 3.99 & & 4.25 & 153 & 2 & 3.93 & 3.58 & 18 & & & 96 & 58 & 4.22 & 0.134 \\
\hline${ }^{3} \mathrm{M}^{3}$ & 19 & 6.15 & 5.93 & 6.48 & 147 & 2 & 6.07 & 5.68 & & & 4 & 6.07 & .71 & 6.53 & 0.204 \\
\hline 3 & 19 & 6.23 & 6. & 6.62 & 157 & 2 & 6.19 & 5.80 & 48 & & 5 & 6.24 & .70 & 6.57 & 0.169 \\
\hline & 19 & 2.99 & & 3.29 & 119 & 2 & 3.17 & 2.84 & 3.42 & 121 & 5 & 3.18 & .89 & 3.50 & 0.137 \\
\hline 3 & 19 & 1.02 & & 1.11 & 0 & 7 & 1.05 & 0.90 & 1.28 & 075 & 4 & 1.05 & 90 & .16 & 0.064 \\
\hline & 19 & 0.47 & & 0.57 & & 72 & 0.49 & 0.38 & 0.60 & & 4 & 0.49 & 37 & 57 & 0.047 \\
\hline & 19 & 1.17 & & 1.27 & & & 1.24 & 1.03 & 1.36 & & 5 & 1.23 & 10 & 35 & 0.071 \\
\hline & 19 & 1.32 & & 1.51 & 071 & & 1.33 & 1.18 & 1. & & 5 & 1.32 & 18 & 42 & 0.053 \\
\hline & 19 & 3.41 & & 3.6 & & & 3.50 & & & & & .49 & & 79 & 0.111 \\
\hline & 19 & 1.53 & & 70 & & & 1.59 & 1.42 & 1.86 & & 5 & 1.58 & & 70 & 0.058 \\
\hline & 19 & 1.77 & & 93 & & 72 & 1.82 & 1. & 1. & & 5 & 1.81 & & 95 & 0.067 \\
\hline & 19 & 1.69 & & & & 72 & 69 & & & & 5 & 71 & & 94 & 0.069 \\
\hline & 19 & 11.53 & 11.0 & 11.93 & & 72 & 11.46 & 10.78 & 12.08 & & 5 & 11.52 & 10.82 & .02 & 0.289 \\
\hline & 18 & 3.39 & & & 0. & 72 & 3.39 & 2.94 & 3. & & 5 & 3.43 & 17 & 3.71 & 0.120 \\
\hline $\mathrm{CM}_{3}$ & 19 & 6.67 & 6.42 & 7.22 & 0.190 & 72 & 6.64 & 6.25 & 7.05 & 0.165 & 35 & 6.64 & 6.12 & 6.90 & 0.167 \\
\hline $\mathrm{CC} / \mathrm{C}$ & 19 & 0.640 & 0.554 & 0.663 & 0.026 & 72 & 0.635 & 0.592 & 0.670 & 0.021 & 35 & 0.634 & 0.597 & 0.656 & 0.016 \\
\hline $\mathrm{M}^{3} / \mathrm{LCr}$ & 19 & 0.396 & 0.388 & 0.405 & 0.005 & 72 & 0.399 & 0.385 & 0.414 & 0.006 & 35 & 0.401 & 0.386 & 0.412 & 0.006 \\
\hline LaInf/LCr & 19 & 0.244 & 0.233 & 0.260 & 0.008 & 72 & 0.239 & 0.226 & 0.260 & 0.007 & 35 & 0.242 & 0.226 & 0.263 & 0.009 \\
\hline $\mathrm{LaN} / \mathrm{LCr}$ & 19 & 0.470 & 0.443 & 0.500 & 0.013 & 72 & 0.472 & 0.453 & 0.515 & 0.011 & 35 & 0.470 & 0.442 & 0.509 & 0.013 \\
\hline $\mathrm{ANc} / \mathrm{LaN}$ & 19 & 0.793 & 0.773 & 0.821 & 0.017 & 72 & 0.779 & 0.725 & 0.827 & 0.022 & 35 & 0.790 & 0.682 & 0.829 & 0.026 \\
\hline & 19 & 0.373 & 0.363 & 0.391 & 0.009 & 72 & 0.368 & 0.349 & 0.381 & 0.008 & 35 & 0.371 & 0.347 & 0.386 & 0.010 \\
\hline $\mathrm{P}^{2} \mathrm{P}^{3} / \mathrm{LCr}$ & 19 & 0.065 & 0.059 & 0.070 & 0.004 & 72 & 0.067 & 0.059 & 0.096 & 0.005 & 34 & 0.068 & 0.058 & 0.074 & 0.004 \\
\hline $\mathrm{P}^{2} \mathrm{P}^{3} / \mathrm{CM}^{3}$ & 19 & 0.164 & 0.147 & 0.178 & 0.009 & 72 & 0.169 & 0.147 & 0.192 & 0.012 & 34 & 0.169 & 0.142 & 0.184 & 0.010 \\
\hline $\mathrm{LP}^{3} / \mathrm{P}^{2} \mathrm{P}^{3}$ & 19 & 0.461 & 0.301 & 0.527 & 0.050 & 72 & 0.474 & 0.348 & 0.576 & 0.039 & 34 & 0.462 & 0.395 & 0.535 & 0.032 \\
\hline $\mathrm{LaM}^{3} / \mathrm{M}^{1} \mathrm{M}^{3}$ & ${ }^{3} 19$ & 0.497 & 0.469 & 0.517 & 0.012 & 72 & 0.482 & 0.410 & 0.508 & 0.016 & 35 & 0.490 & 0.462 & 0.511 & 0.012 \\
\hline $\mathrm{LaM}^{3} / \mathrm{LaM}^{1}$ & 19 & 1.112 & 1.00 & 1.228 & 0.057 & 72 & 1.065 & 0.901 & 1.161 & 0.047 & 35 & 1.084 & 1.019 & 1.186 & 0.034 \\
\hline & 19 & -0.790 & 1.200 & & 0.775 & $72-$ & -0.774 & 1.005 & -2.465 & 0.687 & 5 & -0.647 & 1.136 & -1.935 & 0.761 \\
\hline & 19 & -1.140 & & & & 72 & & & 2.114 & & & -0.011 & & & 0.994 \\
\hline & 19 & 1.36 & -0.1 & 2.34 & & 72 & & -3.437 & 2.554 & & 35 & 0.159 & & 2.451 & 0.910 \\
\hline $\mathrm{PC} 2$ ind & 19. & -0.187 & 1.691 & -1.789 & 0.906 & 72. & -0.426 & 1.341 & -2.498 & 0.910 & 35. & -0.309 & 2.149 & -1.754 & 0.823 \\
\hline
\end{tabular}

the Omani bats (LaN/LCr 0.456-0.458; ANc/LCr 0.368-0.377), relatively narrow and medium-high braincase in the bats from Crimea (LaN/LCr 0.447-0.455; ANc/LCr 0.351-0.367), and relatively narrow and low braincase in the bats of the SE Middle East (LaN/LCr 0.450-0.467; $\mathrm{ANc} / \mathrm{LCr}$ 0.354-0.361). 
Table 1. (continued)

\begin{tabular}{|c|c|c|c|c|c|c|c|c|c|c|c|c|c|c|c|}
\hline \multirow[t]{2}{*}{ variable } & \multicolumn{5}{|c|}{ East Balkans (EB) } & \multicolumn{5}{|c|}{ North Levant (NL) } & \multicolumn{5}{|c|}{ Cyprus (CY) } \\
\hline & $\mathrm{n}$ & $\mathbf{M}$ & $\min$ & $\max$ & SD & $\mathrm{n}$ & M & $\min$ & $\max$ & SD & 1 & M & $\min$ & $\max$ & \\
\hline & 118 & 40.08 & 36.0 & 45.0 & 1.340 & 28 & 39.81 & 37.8 & 41.8 & 1.238 & 11 & 38.88 & 37.0 & 42.1 & 1.537 \\
\hline & & & & & & & & & & & & & & & \\
\hline & & & & & & & & & & & & & & & \\
\hline & & .72 & & & & & & & & & & & & & \\
\hline & & & & & & & & & & & & & & & \\
\hline & & & & & & & & & & & & & & & \\
\hline & & 36 & & & & & & & & & & & & & \\
\hline & & & & & & & & & & & & & & & \\
\hline & & & & & & & & & & & & & & & \\
\hline & & & & & & & & & & & & & 88 & & \\
\hline & & & & & & & & & & & & & & & \\
\hline & & & & & & & & & & & & & & & \\
\hline & & & & & & & & & & & & & & & \\
\hline & & & & & & & & & & & & & & & \\
\hline & & & & & & & & & & & & & & & \\
\hline & & & & & & & & & & & & & & & \\
\hline & & 56 & & & & & & & & & & & 50 & & \\
\hline & & & & & & & & & & & & & 61 & & \\
\hline & & & & & & & & & & & & & & & \\
\hline & & & & & & & & & & & & & & & \\
\hline & & & & & & & & & & & & & & & \\
\hline & & & & & & & & & & & & & & & \\
\hline & & 6.76 & 6.22 & & & 43 & 0.19 & 6.39 & & & & 6.68 & 6.44 & & \\
\hline & & & & & & & & & & & & & & & \\
\hline & & 404 & & & & & & & & & & & & & \\
\hline & & 0.245 & & & & & & 228 & & & & & .242 & & 0.006 \\
\hline & 104 & 0.468 & & & & & & & & & & & 450 & & 0.009 \\
\hline & J 102 & 0.782 & & & & & & & & & & & 0.748 & & 0.013 \\
\hline & 100 & 0.366 & & & & & & & & & & & 0.347 & & \\
\hline & & 0.069 & & 7 & & & 0.066 & & & & & & 0.062 & & 0.00 \\
\hline & 108 & 0.172 & & & & & & & & & & & 0.153 & & 0.01 \\
\hline & 108 & & & & & & & & & & & & 0.398 & & 0.03 \\
\hline & $\beta 108$ & 0.490 & & & & & & & & & & & 0.476 & & 0.013 \\
\hline & $1^{1} 108$ & 1.093 & & & & & & 0.777 & & & & & 1.000 & & 0.033 \\
\hline & & & & & & & & & & & & & & & 0.526 \\
\hline & & & & & & & & & & & & & & & 0.579 \\
\hline & & & & & & & & & & & & & & & 0.710 \\
\hline $\mathrm{PC} 2$ ind & 108 & -0.480 & 2.075 & -2.347 & 0.848 & 44 & 0.437 & 2.374 & -1.587 & 0.974 & & -0.337 & 0.709 & -1.425 & 0.782 \\
\hline
\end{tabular}

Fig. 4. Univariate plots of compared samples of Myotis emarginatus (see Fig. 3 for explanations); examples of relative and statistical dimensions (for details concerning the PC analysis results see text). 

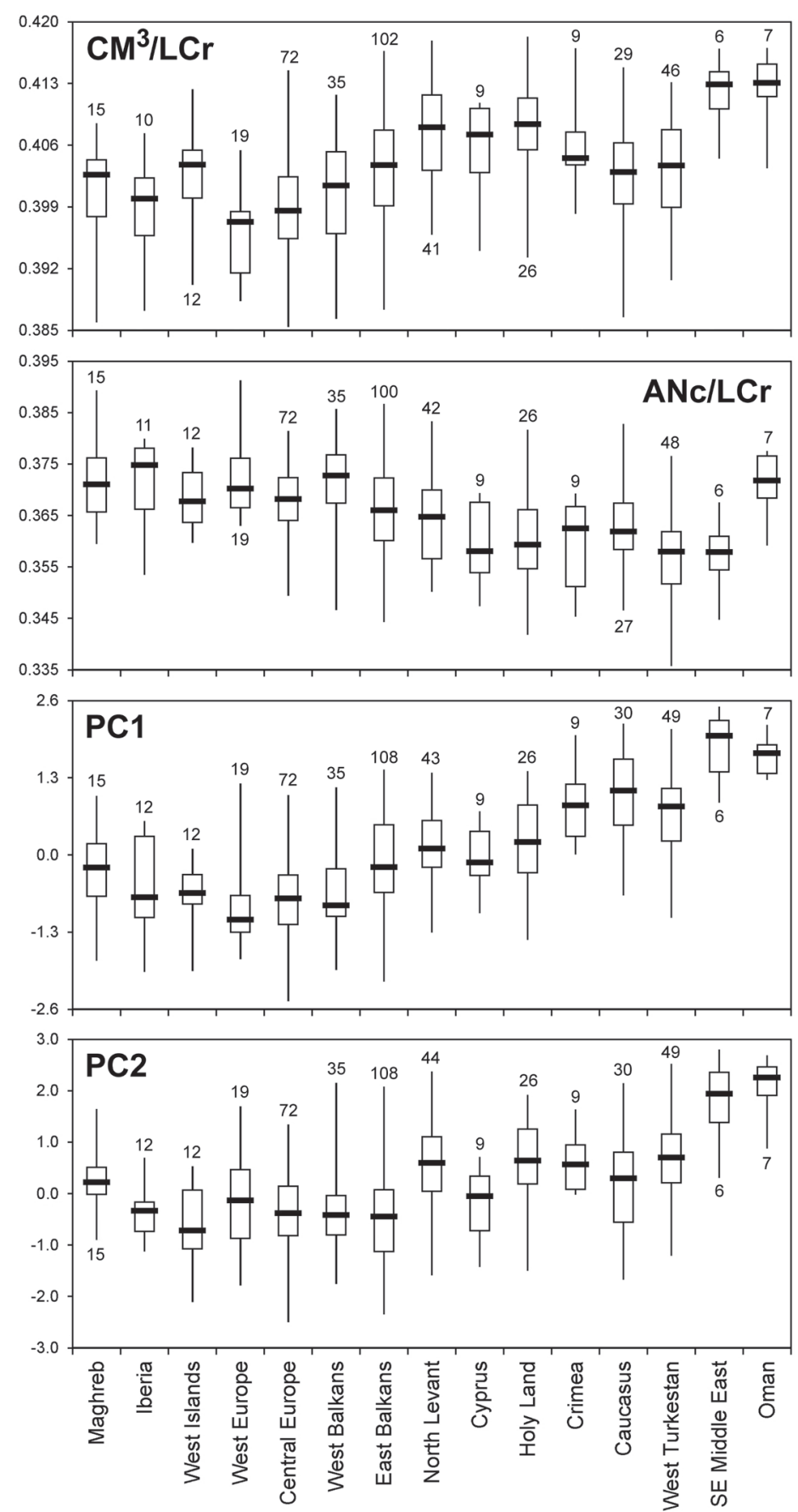
Molar size was evaluated in $M$. emarginatus through the comparison of the upper molar-rows, i.e. the mesio-distal lengths of all three molars $\left(\mathrm{M}^{1} \mathrm{M}^{3}\right)$, and the palato-labial width of particular upper molars $\left(\mathrm{LaM}^{1}, \mathrm{LaM}^{2}, \mathrm{LaM}^{3}\right)$; five basic categories were found concerning these characters (see also Fig. 3). Small upper molars including small $\mathrm{M}^{3}$ were found in the bats from the Maghreb $\left(\mathrm{M}^{1} \mathrm{M}^{3} 3.47-3.63 \mathrm{~mm}\right.$; LaM $\left.{ }^{3} 1.68-1.74 \mathrm{~mm}\right)$, West-Central Europe $\left(\mathrm{M}^{1} \mathrm{M}^{3} 3.34-3.61 \mathrm{~mm} ; \mathrm{LaM}^{3} 1.65-1.79 \mathrm{~mm}\right)$, and the Balkans $\left(\mathrm{M}^{1} \mathrm{M}^{3} 3.42-3.61 \mathrm{~mm} ; \mathrm{LaM}^{3}\right.$ $1.67-1.80 \mathrm{~mm})$. Medium-sized upper molars including medium-sized $\mathrm{M}^{3}$ showed the bats from the Levant ( $\mathrm{M}^{1} \mathrm{M}^{3} 3.61-3.76 \mathrm{~mm}$; $\mathrm{LaM}^{3}$ 1.72-1.85 mm) and Cyprus $\left(\mathrm{M}^{1} \mathrm{M}^{3} 3.55-3.71 \mathrm{~mm}\right.$; $\left.\mathrm{LaM}^{3} 1.73-1.86 \mathrm{~mm}\right)$, while medium-sized upper molars with small $\mathrm{M}^{3}$ were observed in the Crimean bats $\left(\mathrm{M}^{1} \mathrm{M}^{3} 3.56-3.61 \mathrm{~mm}\right.$; $\mathrm{LaM}^{3}$ 1.67-1.74 mm). Large upper molars including large $\mathrm{M}^{3}$ were found in the bats from the SE Middle East $\left(\mathrm{M}^{1} \mathrm{M}^{3} 3.80-3.86 \mathrm{~mm}\right.$; $\left.\mathrm{LaM}^{3} 1.85-1.92 \mathrm{~mm}\right)$ and in the Omani bats $\left(\mathrm{M}^{1} \mathrm{M}^{3} 3.76-3.86 \mathrm{~mm}\right.$; $\mathrm{LaM}^{3}$ 1.84-1.91 mm). Large upper molars but only medium-sized $\mathrm{M}^{3}$ were documented in the bats from the Caucasus $\left(\mathrm{M}^{1} \mathrm{M}^{3} 3.68-3.78 \mathrm{~mm}\right.$; $\left.\mathrm{LaM}^{3} 1.77-1.84 \mathrm{~mm}\right)$ and West Turkestan $\left(\mathrm{M}^{1} \mathrm{M}^{3} 3.53-3.82 \mathrm{~mm}\right.$; $\left.\mathrm{LaM}^{3} 1.71-1.86 \mathrm{~mm}\right)$. Shape differences or marked differences in the relative size of particular molars between the compared sample sets were not found.

The size of the small upper premolars $\left(\mathrm{P}^{2-3}\right)$ was in an intermediate position $\left(\mathrm{P}^{2} \mathrm{P}^{3} / \mathrm{LCr} 0.062-\right.$ 0.070 ) in the majority of $M$. emarginatus sample sets, only three exceptions were found. The bats from the Mediterranean islands showed relatively very large-sized rows of the small upper premolars, both from Cyprus $\left(\mathrm{P}^{2} \mathrm{P}^{3} / \mathrm{LCr} 0.069-0.072\right)$ and West Islands $\left(\mathrm{P}^{2} \mathrm{P}^{3} / \mathrm{LCr} 0.068-0.072\right)$. On the other hand, the Omani bats showed relatively small-sized upper small premolars $\left(\mathrm{P}^{2} \mathrm{P}^{3} /\right.$ LCr 0.059-0.060). The smallest tooth examined, the second upper premolar $\left(\mathrm{P}^{3}\right)$, was found to be the smallest (in absolute values) in the bats from the Maghreb ( $\mathrm{LP}^{3} 0.45-0.49 \mathrm{~mm}$ ), West Europe ( $\left.\mathrm{LP}^{3} 0.44-0.50 \mathrm{~mm}\right)$, and from Oman $\left(\mathrm{LP}^{3} 0.44-0.49 \mathrm{~mm}\right)$, while the largest in the bats from Crimea $\left(\mathrm{LP}^{3} 0.51-0.55 \mathrm{~mm}\right)$ and Caucasus $\left(\mathrm{LP}^{3} 0.50-0.57 \mathrm{~mm}\right)$. In other sample sets, this premolar was found to be medium-sized ( $\mathrm{LP}^{3} 0.46-0.54 \mathrm{~mm}$; Fig. 3).

To summarise the above observations, four basic groups of populations could be sorted out within the distribution range of $M$. emarginatus, based on the absolute and relative metric characters. Moreover, some populations, creating isolated islands within the range (both in sea islands and geographically separated areas), showed again more separated positions in certain aspects. (1) The group of samples from the western and central parts of the Mediterranean Basin, i.e. between the Maghreb and Iberia in the west and the Balkans in the east, including Central Europe $(\mathrm{MG}+\mathrm{IB}+\mathrm{WI}+\mathrm{WE}+\mathrm{CE}+\mathrm{WB}+\mathrm{EB})$, represents small or medium-sized bats, with a relatively rather short and narrow rostrum, wide and high braincase, small molars and small to medium sized premolars; among these samples, the bats from West Islands are the absolutely smallest in the skull and molar sizes and braincase width, and largest in the length of the premolar-row. (2) The group of samples from the Levant, including Cyprus (NL+CY+HL), represents small or medium-sized bats, but with a relatively long and narrow rostrum, and wide and low braincase, medium-sized molars, and small to medium-sized premolars; within this group, the Cypriot samples show a difference in skull size and rostrum shape, being the smallest in body and skull size, largest in rostrum width and the small premolar-row. (3) The group of samples from Crimea, Caucasus and West Turkestan $(\mathrm{CR}+\mathrm{CA}+\mathrm{WT})$, represents large bats, with a relatively narrow and medium-long rostrum, narrow and low braincase, small or mediumsized molars, and relatively rather small premolars; among these samples, the bats from Crimea differed by a relatively very narrow braincase and small third upper molars. (4) The group of samples from Oman, south-eastern Iran and Afghanistan (OM+SM) represents large bats, with 
Table 1. (continued)

\begin{tabular}{|c|c|c|c|c|c|c|c|c|c|c|c|c|c|c|c|}
\hline \multirow[t]{2}{*}{ variable } & \multicolumn{5}{|c|}{ Holy Land (HL) } & \multicolumn{5}{|c|}{ Crimea (CR) } & \multicolumn{5}{|c|}{ Caucasus (CA) } \\
\hline & $\mathrm{n}$ & $\mathbf{M}$ & $\min$ & $\max$ & SD & $\mathrm{n}$ & $\mathbf{M}$ & $\min$ & $\max$ & SD & $\mathrm{n}$ & $\mathbf{M}$ & $\min$ & $\max$ & SD \\
\hline LAt & 26 & 39.73 & 36.4 & 42.6 & 1.323 & 10 & 40.81 & 39.6 & 42.0 & 0.889 & 31 & 41.34 & 39.7 & 43.5 & 0.964 \\
\hline $\mathrm{Cr}$ & 26 & 15.79 & 15.23 & 16.35 & 0.356 & 9 & 16.24 & 15.87 & 16.60 & 0.244 & 29 & 16.19 & 15.68 & 16.74 & 0.287 \\
\hline $\mathrm{Cb}$ & 26 & 14.87 & 14.18 & 15.47 & 325 & 9 & 15.21 & 14.73 & 15.75 & 0.296 & 28 & 15.27 & 14.75 & 16.06 & 278 \\
\hline $\mathrm{aZ}$ & 25 & 9.66 & 9.19 & 9.89 & 171 & 10 & 9.82 & 9.50 & 10.08 & 0.184 & 26 & 9.94 & 9.47 & 10.28 & 0.241 \\
\hline aI & 26 & 3.56 & 3.42 & 3.94 & 121 & 10 & 3.60 & 3.48 & 3.80 & 105 & 30 & .70 & 3.43 & 3.93 & 0.129 \\
\hline $\operatorname{Inf}$ & 26 & 3.84 & 3.68 & 4.05 & & 10 & 3.92 & 3.78 & 4.10 & 117 & 30 & .95 & 3.74 & 4.08 & 0.104 \\
\hline $\mathrm{N}$ & 26 & 7.36 & 7.12 & 7.72 & 135 & 10 & 7.32 & 7.10 & 48 & 141 & 29 & 48 & 7.08 & 74 & 0.170 \\
\hline $\mathrm{Nc}$ & 26 & 5.70 & 5.41 & 6.05 & 189 & 9 & 5.83 & 5.67 & 03 & 104 & 27 & 88 & 5.59 & 14 & 0.151 \\
\hline & 2 & 4.02 & 3.80 & 4.25 & 118 & 10 & 4.15 & 4.02 & 28 & 105 & 30 & 11 & .85 & 32 & 0.133 \\
\hline${ }^{3} \mathrm{M}^{3}$ & 2 & 6.23 & 5.87 & 6.45 & & 10 & 6.29 & 6.15 & 6.48 & 134 & 30 & 36 & 6.02 & 63 & 0.164 \\
\hline M & 26 & 6.44 & 6.11 & 6.68 & 141 & 10 & 6.57 & 6.42 & 6.78 & 111 & 31 & .52 & .18 & 76 & 0.131 \\
\hline & 13 & 3.28 & 3.00 & 3.45 & & 10 & 3.21 & 3.08 & 3.32 & 090 & 30 & .35 & 3.03 & 3.53 & 0.113 \\
\hline 3 & 14 & 1.05 & 0.95 & 1.19 & & 10 & 1.06 & 0.98 & 1 . & 065 & 30 & 1.07 & 0.91 & 19 & 0.067 \\
\hline & 14 & 0.50 & 0.41 & 0.60 & & 10 & 0.53 & 0.47 & & 031 & 30 & 53 & 0.43 & 60 & 0.041 \\
\hline & 1 & 25 & & 1.33 & & 10 & 1.25 & 1.17 & & 046 & 30 & 36 & .16 & 48 & 0.110 \\
\hline & 1 & 37 & 1.2 & 1.43 & & 10 & 1.37 & 1.30 & 1 & 047 & 30 & .45 & 1.30 & 53 & 0.054 \\
\hline & 1 & 3.68 & & 3.84 & & 10 & 3.58 & 3.42 & & & 30 & 72 & .39 & 87 & 0.105 \\
\hline & 1 & 1.6 & & 1.77 & & 10 & 1.63 & 1.55 & & 0 & 30 & 1.72 & 1.54 & 80 & 0.059 \\
\hline & 1 & 1. & & 1.95 & & 10 & 1.85 & 1.74 & & & 0 & 1.95 & 1.78 & 94 & 0.053 \\
\hline & 14 & 1.78 & & & & 10 & 1.72 & 1.65 & & & 0 & .81 & 65 & 96 & 0.092 \\
\hline & 26 & 11.72 & 11.03 & 12.20 & & 9 & 11.97 & 11.64 & 12.45 & 301 & 31 & 12.03 & 11.62 & & 0.178 \\
\hline & 26 & 3.50 & 3.1 & 3.75 & 0.144 & 9 & 3.67 & 3.40 & 3. & 0. & 29 & 3.58 & 2.76 & 81 & 0.197 \\
\hline $\mathrm{CM}_{3}$ & 26 & 6.85 & 6.53 & 7.18 & 0.174 & 10 & 7.02 & 6.85 & 7.20 & 0.118 & 31 & 6.97 & 6.61 & 7.23 & 0.125 \\
\hline $\mathrm{CC} / \mathrm{C}$ & 25 & 0.624 & 0.573 & 0.656 & 0.020 & 10 & 0.632 & 0.608 & 0.649 & 0.012 & 30 & 0.631 & 0.588 & 0.680 & 0.023 \\
\hline $\mathrm{CM}^{3} / \mathrm{LCr}$ & 26 & 0.408 & 0.393 & 0.418 & 0.005 & 9 & 0.406 & 0.398 & 0.417 & 0.005 & 29 & 0.403 & 0.386 & 0.415 & 0.007 \\
\hline LaInf/LCr & 26 & 0.243 & 0.229 & 0.258 & 0.008 & 9 & 0.241 & 0.234 & 0.252 & 0.006 & 29 & 0.244 & 0.229 & 0.256 & 0.007 \\
\hline $\mathrm{LaN} / \mathrm{LCr}$ & 26 & 0.466 & 0.443 & 0.486 & 0.011 & 9 & 0.451 & 0.443 & 0.460 & 0.006 & 29 & 0.462 & 0.430 & 0.482 & 0.011 \\
\hline $\mathrm{ANc} / \mathrm{LaN}$ & 26 & 0.775 & 0.728 & 0.813 & 0.022 & 9 & 0.795 & 0.765 & 0.820 & 0.018 & 27 & 0.788 & 0.749 & 0.834 & 0.020 \\
\hline & 26 & 0.361 & 0.342 & 0.382 & 0.010 & 9 & 0.359 & 0.345 & 0.369 & 0.009 & 27 & 0.363 & 0.347 & 0.383 & 0.008 \\
\hline $\mathrm{P}^{2} \mathrm{P}^{3} / \mathrm{LCr}$ & 14 & 0.067 & 0.061 & 0.076 & 0.003 & 9 & 0.066 & 0.061 & 0.074 & 0.004 & 29 & 0.066 & 0.056 & 0.073 & 0.004 \\
\hline $\mathrm{P}^{2} \mathrm{P}^{3} / \mathrm{CM}^{3}$ & 14 & 0.163 & 0.149 & 0.183 & 0.011 & 10 & 0.162 & 0.153 & 0.177 & 0.008 & 30 & 0.164 & 0.141 & 0.182 & 0.010 \\
\hline $\mathrm{LP}^{3} / \mathrm{P}^{2} \mathrm{P}^{3}$ & 14 & 0.477 & 0.415 & 0.564 & 0.041 & 10 & 0.495 & 0.445 & 0.537 & 0.026 & 30 & 0.496 & 0.406 & 0.644 & 0.043 \\
\hline $\mathrm{LaM}^{3} / \mathrm{M}^{1} \mathrm{M}$ & {$\left[\begin{array}{l}3 \\
14\end{array}\right.$} & 0.483 & 0.462 & 0.500 & 0.013 & 10 & 0.480 & 0.468 & 0.498 & 0.010 & 30 & 0.483 & 0.376 & 0.515 & 0.024 \\
\hline $\mathrm{LaM}^{3} / \mathrm{LaM}^{1}$ & ${ }^{1} 14$ & 1.064 & 0.952 & 1.154 & 0.051 & 10 & 1.055 & 1.032 & 1.082 & 0.022 & 30 & 1.044 & 0.811 & 1.136 & 0.056 \\
\hline PC1 dim & 26 & 0.304 & 1.406 & -1.433 & 0.694 & 9 & 0.765 & 2.013 & 0.009 & 0.668 & 30 & 1.279 & 2.212 & -0.679 & 0.578 \\
\hline & 26 & 0.286 & & 1.436 & & 9 & & -2.303 & -0.481 & 0.560 & 30 & 0.307 & -1.834 & 1.7 & 0.847 \\
\hline & 26 & -0.71 & & 1.084 & 0.902 & 9 & & -1.810 & 1.393 & 0.827 & 30 & -0.09 & -1.761 & 2.18 & 1.017 \\
\hline $\mathrm{PC} 2$ ind & 26 & 0.595 & 1.919 & -1.503 & 0.766 & 9 & 0.616 & 1.632 & -0.017 & 0.597 & 30 & 0.186 & 2.145 & -1.671 & 0.953 \\
\hline
\end{tabular}

a relatively very long and medium-wide to very wide rostrum, narrow braincase, large molars, and small premolars; these two population sets differ from each other by the relative height of braincase, being small in the SE Middle Eastern bats but large in the Omani bats, and by the relative length of the premolar-row $\left(\mathrm{P}^{2} \mathrm{P}^{3} / \mathrm{LCr}\right)$, being medium-large in the former sample set, but very small (smallest among all examined samples) in the Omani bats. 
Table 1. (continued)

\begin{tabular}{|c|c|c|c|c|c|c|c|c|c|c|c|c|c|c|c|}
\hline \multirow[t]{2}{*}{ variable } & \multicolumn{5}{|c|}{ West Turkestan (WT) } & \multicolumn{5}{|c|}{ SE Middle East (SM) } & \multicolumn{5}{|c|}{ Oman (OM) } \\
\hline & $\mathrm{n}$ & M & $\min$ & $\max$ & SD & $\mathrm{n}$ & M & $\min$ & $\max$ & SD & & $\mathbf{M}$ & $\min$ & $\max$ & SD \\
\hline At & 50 & 41.75 & 38.6 & 45.1 & 1.553 & 4 & 43.18 & 41.2 & 44.2 & 1.391 & 8 & 41.63 & 40.8 & 42.9 & 0.643 \\
\hline & 48 & & .05 & 16.62 & 33 & 6 & & 5.65 & 16.79 & 0.4 & & 6.06 & 5.73 & 16.46 & 20 \\
\hline & & & & & & & & & & & & & & & \\
\hline & 4 & & 9.60 & 10.17 & & 5 & 9.96 & & 10.17 & & & & 9.62 & & 266 \\
\hline & & & & & & & & & & & & & & & 0.098 \\
\hline & & & & & & & 4.04 & & & & & & & & 0.146 \\
\hline & & & & & & & & & & & & & & & 0.118 \\
\hline & & & & & & & & & & & & & & & 157 \\
\hline & & & & & & & & & & & & & & & 112 \\
\hline & & & & & & & & & & & & & & & 139 \\
\hline & 4 & & & & & & & & & & & & & & 091 \\
\hline & 4 & & & & & & & & & & & 36 & & & 084 \\
\hline & 4 & & & & & & & & & & & 96 & & & 040 \\
\hline & & & & & & & & & & & & & & & 028 \\
\hline & & & & & & & & & & & & & & & .047 \\
\hline & & & & & & & & & & & & & & & 044 \\
\hline & 4 & & & & & & & & & & & & & & \\
\hline & & & & & & & & & & & & & & & 057 \\
\hline & & & & & & & & & & & & & & & \\
\hline & 4 & & & & & & & & & & & & & & \\
\hline & 5 & & & & & 7 & & & & & & & & & \\
\hline & 4 & & & & & 7 & & & & & & & & & 113 \\
\hline $\mathrm{CM}_{3}$ & 50 & .97 & 45 & 7.32 & & 7 & 7.13 & & & & & 6.98 & .82 & & 0.120 \\
\hline & 46 & & & & & 7 & & & & & & & & & \\
\hline & 46 & & & & & 6 & & & & & & & & & 0.004 \\
\hline & 48 & & & 0.2 & & 6 & & 0.2 & & & & & & & 0.008 \\
\hline & 48 & & & & & 6 & & & & & & & 0.451 & & 0.003 \\
\hline & 48 & & & & & 6 & & & & & & & & & 0.015 \\
\hline & 48 & & & & & 6 & & & & & & & & & 0.007 \\
\hline & 48 & & & $0.0^{\circ}$ & & 4 & & & & & & & & & 0.002 \\
\hline & 48 & & & 0.1 & & 4 & & & & & & & 0.1 & & 0.006 \\
\hline & 49 & $0.4^{\prime}$ & & 0.5 & & 4 & & & 0.5 & & & & & & 0.026 \\
\hline & 349 & 0.489 & & & & 4 & & & & & & & & & 0.010 \\
\hline & 49 & 1.080 & 0.9 & 1.1 & & 4 & & & & & & & & & 0.040 \\
\hline & 49 & 0.765 & & & & 6 & & & 0.8 & & & & & & 0.582 \\
\hline & $49-$ & & & & & 6 & & & & & & & & & 0.726 \\
\hline & 49 & & & & & 6. & & & & & & & & & 0.482 \\
\hline $\mathrm{PC} 2$ ind & 49 & 0.690 & 2.522 & -1.209 & 0.767 & 6 & 1.560 & 2.801 & -0.301 & 1.018 & & 2.179 & 2.689 & 0.877 & 0.655 \\
\hline
\end{tabular}

The results of the principal component analysis well described the size and shape trends in the west-east scope of the geographic range of M. emarginatus (Fig. 4). The results of the analysis employing 15 skull plain dimensions most important for description of the inter-population differences ( $\mathrm{LCr}, \mathrm{LCb}, \mathrm{CC}, \mathrm{M}^{3} \mathrm{M}^{3}, \mathrm{CM}^{3}, \mathrm{CP}^{4}, \mathrm{P}^{2} \mathrm{P}^{3}, \mathrm{LP}^{4}, \mathrm{LaP}^{4}, \mathrm{LaM}^{1}, \mathrm{LaM}^{2}, \mathrm{LaM}^{3}$, $\mathrm{LMd}, \mathrm{ACo}, \mathrm{CM}_{3}$ ) showed a trend of (geographically interrupted) cline increasing of the skull 
size from the western Mediterranean in the west to the south-eastern part of the Middle East in the east. The 1 st component of these results (covering $49.25 \%$ of the total variance) followed the size differences and demonstrated the West and Central European samples to be smallest among the sample sets, while the samples from Oman and SE Middle East to be the largest, with the Levantine (incl. Cypriot) samples to be medium-sized and the Crimean, Caucasian, and Turkestani bats being intermediate in size between the latter two groups (Fig. 4). Similarly, the results of the analysis employing seven relative dimensions selected as most important in the inter-population differences $\left(\mathrm{CC} / \mathrm{CM}^{3}, \mathrm{CM}^{3} / \mathrm{LCr}, \mathrm{CP}^{4} / \mathrm{LCr}, \mathrm{P}^{2} \mathrm{P}^{3} / \mathrm{LCr}, \mathrm{LaM}^{3} / \mathrm{M}^{1} \mathrm{M}^{3}, \mathrm{LaM}^{3} / \mathrm{LaM}^{1}\right.$ ) sorted out groups following the differences given mostly by shapes of the skull and/or teeth. The 2nd component of these results (covering $24.63 \%$ of the total variance) separated three main population groups (Fig. 4); (1) bats with a relatively long and wide rostrum, large molars and small premolars from SE Middle East and Oman, (2) bats with a relatively long and narrow rostrum, medium-sized molars and premolars from the Levant (excl. Cyprus), Crimea, Caucasus, and West Turkestan, and (3) bats with a relatively short and narrow rostrum, small molars and premolars from the Mediterranean Basin (excl. the Levant) and Central Europe.

The results of the cluster analysis (UPGMA, Euclidean distances) computed from the percentages of the mean metric differences in morphometric traits between particular sample sets, employing all collected 23 plain dimensions of the body, skull and teeth, and 13 relative dimensions of the skull and teeth (see Table 1), showed very similar divisions of the geographic sets of $M$. emarginatus, as they were observed from the empiric morphometric comparisons and described above (Fig. 5). The geographic content of the species was splitted into two main groups, Asian and Euro-Mediterranenan; the Asian group was again divided into two groups,

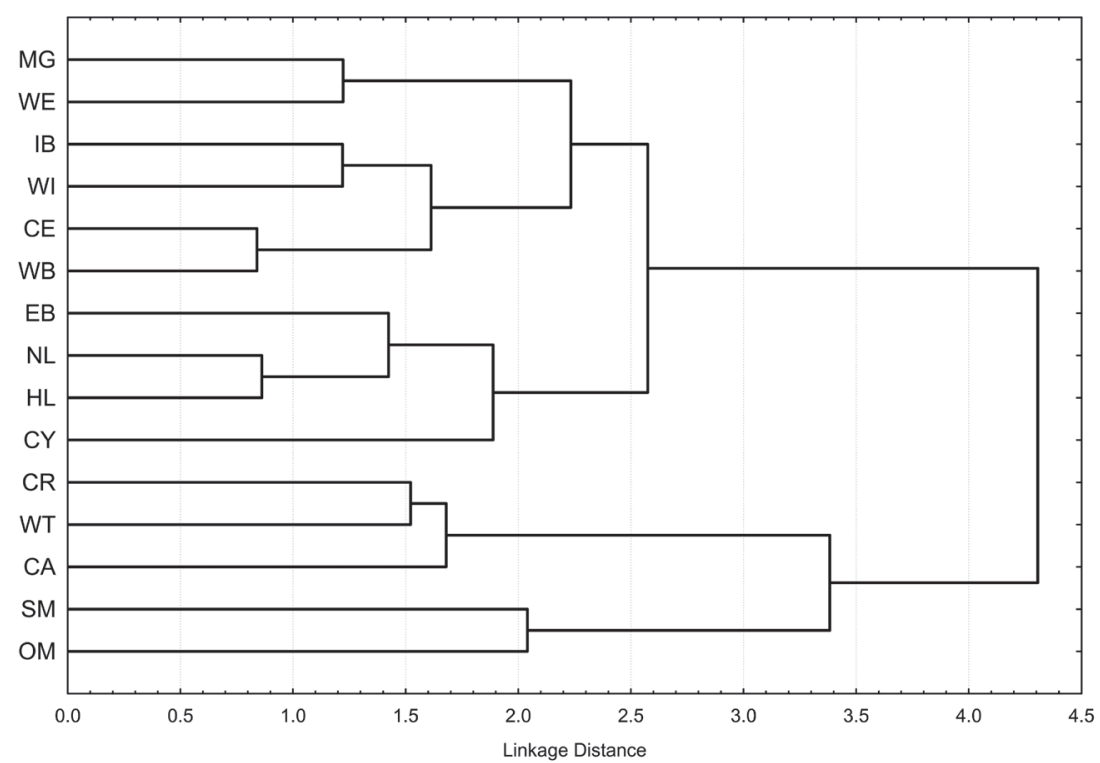

Fig. 5. Similarities among geographic sample sets of Myotis emarginatus based on the results of cluster analysis (UPGMA) of the mean values of 23 plain dimensions and 13 relative dimensions. 
the northern populations (Crimea, Caucasus, West Turkestan) and south-eastern populations (Oman, south-eastern Middle East), and the Euro-Mediterranean group also in two subgroups, the East-Mediterranen populations (East Balkans, North Levant, Holy Land, Cyprus) and the West-Mediterranean and Central European populations (Maghreb, Iberia, West Europe, West Islands, Central Europe, West Balkans).

\section{DISCUSSION}

As reviewed in detail above, the intraspecific classification in Myotis emarginatus was proposed several times and the number of taxonomic units within this species varied between two and four. While the populations of the broad area of the European and African Mediterranean and of Central Europe were considered to belong to only one subspecies, one to four subspecies were reported from the Asian part of the species range. This divergence implies that the Asian populations play a crucial role in understanding of phylogenetic relations within the species. Our analysis covered most of the Mediterranean range of the species and for the first time, the comparison included a majority of the Asian populations of M. emarginatus. Only the samples from the north-eastern margin of Mesopotamia and from south-western Arabia were unavailable for examination and their position within the species phylogeny was not evaluated.

Our analysis uncovered the existence of four main, geographically exclusive morphotypes in M. emarginatus, concerning the body, skull and tooth sizes, and skull and tooth shapes: (1) rather small bats with a short rostrum and high braincase, occurring in Europe and north-western Africa; (2) rather medium-sized bats with a long rostrum and short braincase from the Levant including Cyprus; (3) large bats with a wide and long rostrum from the south-eastern parts of the Middle East, including Oman, south-eastern Iran and eastern Afghanistan, and (4) large bats with a narrow rostrum, occurring in Crimea, the Caucasus region, and West Turkestan. Such a shift of metric characteristics within the south-west Palaearctic range, with smallest bats in the west and largest bats in the east, was previously observed in several other bat taxa (see e.g. Bogdanowicz 1990, BENDA \& HoráČ́EK 1995, BENDA \& Gvoždík 2010) and thus, in $M$. emarginatus it could be considered just a common pattern present in bats in general. However, unlike the body and skull size, the variation in skull shape did not show the cline shift, and moreover, the "shift" in the metric traits in M. emarginatus is not continual, i.e. it does not represent a typical cline, found in some other Myotis species of the western Palaearctic (cf. BOGDANOWICZ 1990, BENDA \& HORÁČEK 1995).

Additionally, the results of the mitochondrial genetic analysis of $M$. emarginatus performed by UVIZL \& BENDA (2021a) revealed an existence of three main lineages within the species rank; (1) Euro-Mediterranean lineage, (2) South Iranian and Omani lineage, and (3) Caucasian and West Turkestani lineage. The Euro-Mediterranean lineage was again divided into three sublineages, Euro-Maghrebian, North Levantine, and South Levantine (Holy Land). The lineages well conform in the geographic delimitations to the above defined morphotypes, with an exception of the Levantine morphotype, which belongs to two sublineages, North Levantine and South Levantine (Holy Land), respectively. Both these East-Mediterranean sublineages, although well separated geographically, were neither supported statistically nor by significant genetic distances among the populations, which were only shallow (UVIZL \& BENDA 2021a).

Thus, the morphotypes and genetic lineages could be integrated into natural phylogenetic units as follows: (1) western bats, comprising the small- and medium-sized morphotypes of the bats from Europe, North Africa and the Levant, and the lineages from the Mediterranean, North 
Levant and Holy Land; (2) south-eastern bats, comprising the large sized morphotype from the south-eastern parts of the Middle East and the lineage from southern Iran and Oman; and (3) north-eastern bats, comprising the large-sized morphotype from Crimea, Caucasus, and West Turkestan, and the lineage from the Causcasus region and West Turkestan. Since the differences between these units are formally quantified by the genetic distances of the cytochrome $b$ gene in the range of $0.93-2.13 \%$ (UVIZL \& BENDA 2021a), these three phylogenetically and geographically separated units could be regarded as subspecies of $M$. emarginatus.

This conception modifies the conclusions presented by UVIZL \& BENDA (2021a) concerning the Asian populations of $M$. emarginatus. These conclusions were based on the results of a profound molecular genetic analysis in a combination with results of the preliminary metric comparison by BENDA et al. (2006). The latter comparison differentiated two basic size categories among the samples of $M$. emarginatus, small western bats and large eastern bats, and this rather superficial view was supported by the basic separation of the mitochondrial sequences and with the biogeographic data - the western and eastern bats live in an apparent allopatry, being separated by a broad gap in the species occurrence in the central parts of the Middle East, some 400-600 km wide. However, the results presented here corroborate much better the three subspecies conception, which much better follows the results of analysis of the mitochondrial markers as well as the results of a fine morphologic analysis, covering besides the size traits also the skull shape and dental characters, and mainly, a much more representative set of samples from all substantial range parts. The biogeographic aspect could also be applied, since the two eastern lineages are well separated by desert or mountain areas (see below for more detailed comments), i.e., in a degree similar to the isolation of the western bats.

The conception of the unit of western bats intergrates the populations of $M$. emarginatus of the whole Mediterranean Basin and all parts of Europe (except Crimea and Cis-Caucasia) into one taxon (see also UvizL \& BENDA 2021a). The rather high internal variation within this unit was confirmed by the results of both analyses, the morphologic and genetic comparisons, and is uncomparable to the diversity found in two other units. However, the latter two units cover much smaller numbers of samples, but mainly, much smaller geographic scopes than the unit of the western bats. The morphologic variation in the unit of western bats, evident in body and skull size as well as skull shape, is very probably related to the extremely variable enviroment range stretching from dry scrublands at the southern limits of the occurrence range (Morocco, Israel, Jordan), where the large-sized bats live, to rather humid forests of the range northern limits (Netherlands, Germany, Czech Republic, Poland), where the small-sized bats occur, and which also includes specific conditions in the Mediterranean islands (Corsica, Sardinia, Sicily, Cyprus) with morphologically extremely variable bats. On the other hand, the very shallow genetic variation among the mtDNA haplotypes within this unit $(0.18-0.82 \%)$ supports the phylogenetic compactness of this unit (UVIZL \& BENDA 2021a).

The Levantine populations were separated into two distinct sublineages of the mitochondrial genes (UvizL \& BENDA 2021a), North Levantine and Holy Land ones. However, these mitochondrial groups do no affect the morphologic grouping of these populations, bats of both lineages represent an identical morphotype. The genetic distance between these two sublineages is rather low, 0.46-0.82\% (UvizL \& BENDA 2021a), lower than between the lineages representing the three subspecies considered (see above). The border between the parapatric geographic ranges of these lineages present in the Levant suggests strong philopatry in females of these lineages that, however, has no effect in the real gene flow as showed by the morphometric data. The bats of the Holy Land lineage occur mainly in the upland Mediterranean habitats of the southern 
Levant, while the North Levantine lineage was detected in a mosaic of lowlands and uplands of the northern Levant including Cyprus.

An almost identical geographic division into two phylogenetical groups was found in another bat occurring in the Levant, Myotis hoveli Harrison, 1964 (see UvizL \& BENDA 2021b). This common phylogentic pattern suggest a past existence of isolated refugia temporarily dividing the biota of the Levant into northern and southern segments. Currently the bats descending from these refugia occur in close allopatry or even sympatry (see the maps by UvIZL \& BENDA $2021 \mathrm{a}, \mathrm{b})$ and the former refugial division has affected the local phylogenetic context of the two species (ÇORAMAN et al. 2019, UVIZL \& BENDA 2021a). On the other hand, the territory of Lebanon, where the borderlines between the two lineages in both Myotis species occur, represents a biogeographic boundary as well, where the limits of distribution ranges of several bat species are situated (see BENDA et al. 2016a).

The arrangement of the European, African and Levantine populations into one unit conforms to the opinions of numerous previous authors, who regarded these populations as one common taxon (Ellerman \& Morrison-Scott 1951, Corbet 1978, Harrison \& Bates 1991, KoOpMan 1994, Topál 2001, Karataş \& Özgül 2003, Benda et al. 2006, Dietz et al. 2007, MaYer et al. 2007, AlbayraK 2015, LóPez-Baucells 2019). On the contrary, most of these opinions considered also the populations of Crimea and Caucasus to be a part of this Euro-Mediterranean taxon, but this conception is not supported by our results.

Five names are available from the range of the unit of western bats according to the previous reviews (Miller 1912, Ellerman \& Morrison-Scott 1951, Corbet 1978, Simmons 2005); viz. Vespertilio emarginatus Geoffroy, 1806; V. rufescens Crespon, 1844; V. ciliatus Blasius, 1853; Myotis ciliata budapestiensis Margó, 1880; and Vespertilio neglectus Fatio, 1890. Since all these names were created based on the materials from western or central Europe (France, Germany, Switzerland, Hungary; see MiLlER 1912), i.e. from an area representing just a small segment of the range of the unit of western bats, they naturally constitute synonyms of the prior name, $V$. emarginatus. The latter name is thus also a name for the western subspecies, i.e. $M$. emarginatus emarginatus (Geoffroy, 1806).

The populations of $M$. emarginatus of the Asian range (excluding the Levant) belong to two phylogenetic units, the south-eastern bats and the north-eastern bats, well separated from each other by genetic and morphologic traits, but not in an enormous geographic distance. The south-eastern bats represent the largest representatives of the species, with a relatively very long and rather wide rostrum, thus morphologically most distant from other populations. According to the available records, this unit occurs in the most arid areas of the species range, in southern Iran, eastern Afghanistan and north-eastern Oman, and this part of the species range is geographically separated from the other range segments (Fig. 1). This unit perhaps includes also the populations of south-western Iran (see DEBLASE 1980, BENDA et al. 2012), and maybe also of south-western Arabia (cf. GAUCHER 1995, AL-JUMAILY 2003). Two names originate from the distribution range of this unit, Vespertilio desertorum Dobson, 1875, and Myotis lanaceus Thomas, 1920, both were based on the material collected in eastern Baluchistan, Iran, at sites situated some $50 \mathrm{~km}$ from each other (Jalk and Shastun). Although these forms were primarily considered to be separate species (Dobson 1878, SATUNin 1896, 1914, Bianki 1917, Thomas 1920), now both names are considered synonyms of $M$. emarginatus, and the name lanaceus a junior synonym of the name desertorum. It is clear just from the comparison of the descriptions given by the authors of these names (see BLANFORD 1875: 309; and THOMAS 1920: 933; unfortunately, the type specimen of $M$. lanaceus was not available for examination) as well as 
from the critical opinions by relevant subsequent authors (OGNEV 1928, KuZÂKIN 1935, LAY 1967, DeBlase 1980). Hence, the name M. emarginatus desertorum (Dobson, 1875) apparently represents the valid name of the unit of the south-eastern bats, in accordance with many precedent authors (Ellerman \& Morrison-Scott 1951, Etemad 1969, Corbet 1978, DeBlase 1980, Harrison \& Bates 1991, Simmons 2005, Benda et al. 2006, 2012, Benda \& Gaisler 2015, UVIZL \& BENDA 2021a).

The unit of north-eastern bats comprises populations of $M$. emarginatus living in the longitudinally very large belt of areas, stretching from Crimea, via the Greater Caucasus Mts., Transcaucasia, and the Caspian-Hyrcanian region of northern Iran, to the southern and eastern parts of West Turkestan, including southern Kirghizstan and south-eastern Kazakhstan. This range consists of a very diverse spectrum of environments, including very humid lowland forests of western Georgia and northern Iran, dry scrublands of mountains and upper plateaus of eastern Iran and southern Kirghizstan, mountain forests of the Caucasus, or arid lowland steppes of southern Turkmenistan and Tajikistan. Within this large and variable range, despite its ecologic diversity, M. emarginatus creates one stable morphotype of large bats with a rather short and narrow rostrum. Due to variable humidity conditions in this extensive range, a tinge variation in the pelage colouration was observed and reported by many authors (KUZÂKIN 1965, Strelkov et al. 1978, DeBlase 1980); populations of arid habitats were reported to be pale yellowish-grey while bats of humid environments dark reddish-brown (see the review by BENDA et al. 2006). This colour variation led the previous authors to division of the populations of the unit of north-eastern bats into up to three subspecies, $M$. e. emarginatus in Crimea and Caucasus, M. e. desertorum or M. e. turcomanicus in Turkmenistan and M. e. saturatus / M. e. kuzyakini in eastern Uzbekistan and adjacent areas (KuZÂKIN 1934, 1965, CoRBET 1978, DeBlase 1980, Strelkov 1981). However, as we previously concluded (Benda et al. 2006), the pelage colouration in M. emarginatus is a varying character, adaptive to habitat, and without a direct reflection in the species taxonomy. The evidence available from the present analyses supports this conclusion.

The interconnection of the M. emarginatus populations of Crimea and the Caucasus (including northern Iran) into one taxon is not surprising from the biogeographical perspective, such a relationship is known from other Myotis species (BENDA et al. 2016b, ÇORAMAN et al. 2019, 2020, Uvizl \& BENDA 2021b), although not universally (cf. Topál 1971, STRELKov 1972). The interconnection of the Crimean-Caucasian populations with the populations of West Turkestan is more interesting, considering the distinct ecologic conditions in these regions.

Two descriptions were made in the range of this unit, M. emarginatus turcomanicus Bobrinskoj, 1925 and M. lanaceus saturatus Kuzâkin, 1934, the latter name (being pre-occupied) with a replacement name M. e. kuzyakini Rossolimo et Pavlinov, 1979. Since the name created by BOBRINSKOJ (1925) has a priority over the latter two names, we consider M. e. turcomanicus to represent a valid name of the populations of the north-eastern bats and the remaining two names its junior synonyms.

The geographic distribution of the phylogenetic units / subspecies of M. emarginatus in western Asia-emarginatus in the south-west, turcomanicus in the north, and desertorum in the south-east - does not fully correspond with the opinions presented by previous authors reporting intraspecific divisions in this bat (KuZÂKIn 1965, Corbet 1978, DeBlase 1980, Koopman 1994, Simmons 2005, Benda et al. 2006, 2012, López-BAUCELls 2019). The interpretation based on the present results is closest to the arrangement by BENDA et al. (2006), who, however, joined the present units of north-eastern and south-eastern bats into one taxon based solely on the large 
size of body and skull in these populations and also on the clear geographic separation between the western populations of the Mediterranean and Europe and the eastern populations of the eastern Middle East and the Caucasus region (and others living eastwards). However, results of the molecular genetic analysis supported the separation of the populations of the eastern Middle East into a northern unit (turcomanus) and southern unit (desertorum); M. emarginatus is the only species of the genus Myotis Kaup, 1829, distributed in the southern parts of the Middle East, out of the Mediterranean arboreal zone. These southern populations perhaps became geographically isolated during the past glaciation events and at present occurr only in limited areas, separated by mountains (Zagros, Hindu Kush) and deserts (Lut, Kavir) from the northern populations. This north-south division along the Iranian plateau and the Hindu Kush uplands is perhaps a more common phenomenon in bats, such a division was demonstrated also in Rhinolophus hipposideros (Borkhausen, 1797), a horseshoe bat species occurring in a similar range within the Middle East as M. emarginatus (see SHAHABI et al. 2019). However, the geographic variation in bat populations occurring across the south-eastern Middle East remains insufficiently studied.

To be concluded, the results of our analysis confirmed $M$. emarginatus to be a polymorphic species. Although the geographic variation in this bat is not extensive, its extent and geographic scale conforms to the divisions of three subspecies within its species rank; M. e. emarginatus (Geoffroy, 1806) distributed in the European and African Mediterranean including islands, in western and central Europe, and in the Levant; M. e. desertorum (Dobson, 1875) in the south-eastern part of the Middle East, including southern Iran, Oman and Afghanistan; and M. $e$. turcomanicus Bobrinskoj, 1925 in the north-eastern parts of the Middle East, in Crimea and the Caucasus, and in West Turkestan.

\section{SOUHRN}

Taxonomická revise netopýra brvitého (Myotis emarginatus): podrobná morfometrická analysa a závěrečné vyhodnocení dostupných podkladů (Chiroptera: Vespertilionidae). Netopýr brvitý (Myotis emarginatus) je jediným druhem africké linie rodu Myotis (někdy uznávané jako podrod Chrysopteron) rozšířeným především v palearktické oblasti. Obývá široce několik ekologických zon Evropy, severozápadní Afriky a západní Asie a díky tomu byl vždy považován za polymorfní a polytypický druh. Zatímco v Evropě a v severní Africe byl vždy uznáván jen jeden poddruh tohoto netopýra, až čtyři poddruhy byly rozlišovány v Asii. Ovšem platnost jednotlivých taxonů stejně jako systematická posice jednotlivých populací zůstavaly nejasné - bylo tak nutno provést zevrubnou revisi vnitrodruhové fylogenetické struktury Myotis emarginatus, jejíž výsledky zde předkládáme. Revise je založena na kombinaci publikovaných výsledků molekulárně genetické analysy (UvizL \& BENDA 2021a) s výsledky důkladného morfologického vyšetření rozsáhlého souboru jedinců z téměř celého areálu rozšiŕření druhu. Dřŕve popsaná geografická variabilita mitochondriálních markerů prokázala seskupení haplotypů Myotis emarginatus do tř́ hlavních linií, které se vyskytují allopatricky, (1) v Mediterranní zoně Evropy, Levanty a severní Afriky, (2) v jihovýchodní části Blízkého východu a (3) v severním Iranu a v Západním Turkestanu. Morfologické srovnání odhalilo existenci čtyř hlavních a geograficky vymezených morfotypů v rámci celého druhu, vymezených metrickými znaky tělesnými, lebečními a zubními, a fenetickými znaky lebečními a zubními: (1) spíše malí netopýři s krátkou obličejovou a vysokou mozkovou částí lebky, žijící v Evropě a severozápadní Africe, (2) středně velcí netopýři s dlouhou obličejovou a krátkou mozkovou částí lebky žijící v Levantě včetně Kypru, (3) velcí netopýři se širokou a dlouhou obličejovou částí lebky žijící v jihovýchodní části Blízkého východu, (4) velcí netopýři s úzkou obličejovou částí lebky, žijící na Krymu, Kavkaze a v Západním Turkestanu. Synthesou výsledků obou př́stupů hodnocení geografické variability navrhujeme vymezit v ranku Myotis emarginatus tři poddruhy, rozšířené ve vzájemně isolovaných areálech: Myotis emarginatus emarginatus (Geoffroy, 1806), k němuž náležejí populace Mediterranní Evropy, severozápadní Afriky a Levanty, včetně středomořských ostrovů a střední a západní Evropy; M. e. desertorum (Dobson, 1875) rozšířený na jiho- 
východě Blízkého východu, včetně Omanu, Afghanistanu a jihovýchodního Iranu (snad i v jihozápadním Iranu) a M. e. turcomanicus Bobrinskoj, 1925 rozšířený v pásů území táhnoucího se od Krymu, př̀es Velký Kavkaz, Zakavkazí, Hyrkánskou oblast i aridní části severního Iranu po Západní Turkestan.

\section{A c know ledgements}

We thank Paula Jenkins, Daphne HiLls \& Louise Tomsett (BMNH), Carlos IBÁÑEz \& Javier Juste (EBD), Bronislaw W. Woloszyn (ISEA), Petr Koubek \& Jiří Chamr (IVB), Ján Obuch (JOC), Manuel Ruedi (MHNG), Cécile CALlou \& Allowen Evin (MNHN), Tomáš BartoničKa \& †Jiřŕ Gaisler (MUB), Giuliano Doria (MSNG), Friederike SPITZEnBERGer, Barbara HerZIG-Straschil \& Frank Zachos (NMW), $\uparrow$ Dieter Kock, †Gerhard Storch \& Irina Ruf (SMF), Yoram Yom-Tov (TAU), Zdeněk VermouzeK (VMO), Rainer Hutterer \& Jan Decher (ZFMK), †Petr P. Strelkov \& Galina I. Baranova (ZIN), Thomas KaISER \& Frederik Jessen (ZMH), Sergej V. Kruskop (ZMMU), and Darko Kovačić (ZZZ) for providing access to the museum specimens under their care. The study was supported by the Ministry of Culture of the Czech Republic (\# DKRVO 2019-2023/6.IX.c, 00023252) and through the Institutional Research Support (\# SVV 260571/2021).

\section{REFERENCES}

AlbaYraK İ., 2015: Some taxonomical and biological characteristics of Myotis emarginatus (Mammalia: Chiroptera) in Turkey. Munis Entomology \& Zoology, 10: 489-494.

AL-Jumaity M. M., 2003: First record of Myotis emarginatus (E. Geoffroy 1806) for the Republic of Yemen (Mammalia, Chiroptera, Vespertilionidae). Senckenbergiana Biologica, 82: 243-246.

Al-Sheikhly O. F., HABA M. K., Görföl T. \& CsOrba G., 2016: First confirmed records of two bat species for Iraq: Rhinolophus euryale and Myotis emarginatus. Mammalia, 80: 111-115.

BENDA P. \& GAISLER J., 2015: Bats (Mammalia: Chiroptera) of the Eastern Mediterranean and Middle East. Part 12. Bat fauna of Afghanistan: revision of distribution and taxonomy. Acta Societatis Zoologicae Bohemicae, 79: 267-458.

Benda P. \& GvožDík V., 2010: Taxonomy of the genus Otonycteris (Chiroptera: Vespertilionidae: Plecotini) as inferred from morphological and mtDNA data. Acta Chiropterologica, 12: 83-102.

Benda P. \& HoráčeK I., 1995: Geographic variation in three species of Myotis (Mammalia: Chiroptera) in South of the Western Palearctics. Acta Societatis Zoologicae Bohemicae, 59: 17-39.

Benda P., Andreas M., Kock D., Lučan R. K., Munclinger P., Nová P., Obuch J., Ochman K., Reiter A., Uhrin M. \& Weinfurtoví D., 2006: Bats (Mammalia: Chiroptera) of the Eastern Mediterranean. Part 4. Bat fauna of Syria: distribution, systematics, ecology. Acta Societatis Zoologicae Bohemicae, 70: $1-329$.

Benda P., Faizolâhi K., Andreas M., Obuch J., Reiter A., Ševčík M., Uhrin M., Vallo P. \& Ashrafi S., 2012: Bats (Mammalia: Chiroptera) of the Eastern Mediterranean and Middle East. Part 10. Bat fauna of Iran. Acta Societatis Zoologicae Bohemicae, 76: 163-582.

Benda P., Abi Said M. R., Bou Jaoude I., Karanouh R., Lučan R. K., Sadek R., Ševčík M., Uhrin M. \& HorÁČEK I., 2016a: Bats (Mammalia: Chiroptera) of the Eastern Mediterranean and Middle East. Part 13. Review of distribution and ectoparasites of bats in Lebanon. Acta Societatis Zoologicae Bohemicae, 80: 207-316.

Benda P., Gazaryan S. \& Vallo P., 2016b: On the distribution and taxonomy of bats of the Myotis mystacinus morpho-group from the Caucasus region (Chiroptera: Vespertilionidae). Turkish Journal of Zoology, 40: 842-863.

BIANKI V., 1917: Neizvestniâ v literature mestonahoždeniâ russkih Chiroptera [Unknown in literature records of the Russian bats]. Ežegodnik Zoologičeskago Muzeâ Rossijskoj Akademii Nauk, 22: viii-ix (in Russian, with a subtitle in French).

BlANFORD W. T., 1875: Descriptions of new Mammalia from Persia and Balúchistán. Annals and Magazine of Natural History, Fourth Series, 16: 309-313. 
Blasius J. H., 1853: Beschreibung einer neuen deutschen Fledermaus. Archiv für Naturgeschichte, 19(1): 286-293.

Bobrinskou N. A., 1925: Materialy dlâ fauny letučih myšej Turkestanskogo kraâ. (Zapadnyj Turkestan s Semirečenskoj i Zakaspijskoj oblastâmi, Hiva i Buhara) [Materials on the bat fauna of the Turkestan Province. (Western Turkestan with the Regions of Semirechie and Transcaspia, Khiva and Bukhara).]. Bûlleten Moskovskogo Obŝestva Izpytatelej Prirody, Otdel Biologičeskij, N. S., 34: 330-374 (in Russian, with a summary in English).

Bogdanowicz W., 1990: Geographic variation and taxonomy of Daubenton's bat, Myotis daubentoni, in Europe. Journal of Mammalogy, 71: 205-218.

Çoraman E., Dietz C., Hempel E., Ghazaryan A., Levin E., Presetnik P., Zagmajster M. \& Mayer F., 2019: Reticulate evolutionary history of a western Palaearctic bat complex explained by multiple mtDNA introgressions in secondary contacts. Journal of Biogeography, 46: 343-354.

Çoraman E., Dundarova H., Dietz C. \& MaYer F., 2020: Patterns of mtDNA introgression suggest population replacement in Palaearctic whiskered bat species. Royal Society Open Science, 7(191805): 1-13.

Corbet G. B., 1978: The Mammals of the Palaearctic Region: A Taxonomic Review. British Museum (Natural History) \& Cornell University Press, London \& Ithaca, $314 \mathrm{pp}$.

Crespon J., 1844: Faune méridionale ou Description de tous les animaux vertébrés vivans et fossiles sauvages ou domestiques. Tome premier. Auteur, La Fontaine, Libraires, et M. Lebrun, Nimes \& Montpellier, xxviii $+320 \mathrm{pp}$.

DeBlase A. F., 1980: The bats of Iran: systematics, distribution, ecology. Fieldiana: Zoology, N. S., 4: 1-424.

Dietz C., von Helversen O. \& Nill D., 2007: Handbuch der Fledermäuse Europas und Nordwestafrikas. Biologie, Kennzeichen, Gefährdung. Franckh-Kosmos Verlags, Stuttgart, 399 pp.

Dobson G. E., 1878: Catalogue of the Chiroptera in the Collection of the British Museum. British Museum (Natural History), London, $567 \mathrm{pp}$.

Ellerman J. R. \& Morrison-Scott T. C. S., 1951: Checklist of Palaearctic and Indian Mammals 1758 to 1946. British Museum (Natural History), London, 810 pp.

ETEMAD E., 1969: Pestandaran-e iran: khoffash-haye iran va kelid-e tashkhis-e anha [The Bats of Iran, and the Keys to Identify Them]. University of Tehran, Tehran, 228 pp (in Farsi, with a summary in English).

FAтіO V., 1890: Un nouveau Cheiroptère suisse. Archives des Sciences Physiques et Naturelles, Troisième Période, 24: 509-512.

GAISLER J., 1983: Nouvelles données sur les chiroptères du nord algérien. Mammalia, 47: 359-369.

GAUCHER P., 1995: First record of Geoffroy's bat Myotis emarginatus Geoffroy, 1806 (Mammalia: Chiroptera: Vespertilionidae) in Saudi Arabia. Mammalia, 59: 149-151.

García-MudarRa J. L., IbÁÑez C. \& Juste J., 2009: The Straits of Gibraltar: barrier or bridge to Ibero-Moroccan bat diversity. Biological Journal of the Linnean Society, 96: 434-450.

Geoffroy-Saint-Hilaire [É.], 1806: Sur le genre et les espèces de Vespertilion, l'un des genres de la famille des Chauve-souris. Annales du Muséum d'Histoire Naturelle, 8: 187-205.

HabILov T. K., 1992: Fauna Respubliki Tadžikistan. Tom XX. Čast' VII. Mlekopitâ̂sie. Rukokrylye [The fauna of the Republic of Tajikistan. Volume XX. Part VII. Mammals. Bats]. Izdatel'stvo Doniš, Dušanbe, $352 \mathrm{pp}$ (in Russian).

Harrison D. L., 1964: The Mammals of Arabia. Volume I. Introduction, Insectivora, Chiroptera, Primates. Ernest Benn Limited, London, 192 pp.

HARRISON D. L., 1977: Mammals obtained by the Expedition with a check-list of the mammals of the Sultanate of Oman. Journal of Oman Studies, Special Report, 1: 13-26.

Harrison D. L. \& Bates P. J. J., 1991: The Mammals of Arabia. Second Edition. Harrison Zoological Museum, Sevenoaks, $354 \mathrm{pp}$.

HoráČEK I., HANÁK V. \& GAISLER J., 2000: Bats of the Palearctic Region: A Taxonomic and Biogeographic Review. Pp.: 11-157. In: Woloszyn B. W. (ed.): Proceedings of the VIIIth European Bat Research Symposium. Volume I. Approaches to Biogeography and Ecology of Bats. Chiropterological Information Center, Institute of Systematics and Evolution of Animals PAS, Krakow, 273 pp. 
Ibáñez C., García-Mudarra J. L., Ruedi M., Stadelmann B. \& Juste J., 2006: The Iberian contribution to cryptic diversity in European bats. Acta Chiropterologica, 8: 277-297.

JentinK F. A., 1910: Chrysopteron bartelsii, novum genus et nova species, from Java. Notes from the Leyden Museum, 32: 73-77.

KARATAŞ A. \& ÖzGÜL S. A., 2003: On the occurrence of Geoffroy's bat, Myotis emarginatus (Geofroy, 1806), in Turkey (Chiroptera: Vespertilionidae). Zoology in the Middle East, 28: 17-24.

Koopman K. F., 1994. Chiroptera: Systematics. Pp.: 1-217. In: Niethammer J., Schliemann H. \& Starck D. (eds.): Handbuch der Zoologie. Band VIII. Mammalia. Teilband 60. Walter de Gruyter, Berlin \& New York, 223 pp.

Kowalski K. \& RZEBIK-Kowalska B., 1991: Mammals of Algeria. Zakład Narodowy im. Ossolińskich - Wydawnictwo, Kraków, 370 pp.

KuZÂKIN A. P., 1934: Letučie myši g. Taškenta i sistematičeskie zametki o nekotorih formah Chiroptera s Kavkaza, Buhary i Turkmenii [The bats of the city of Tashkent and systematical remarks on several forms of the Chiroptera from the Caucasus, Bukhara and Turkmenistan]. Bûlleten Moskovskogo Obŝestva Izpytatelej Prirody, Otdel Biologičeskij, N. S., 43: 316-330 (in Russian, with a summary in English).

KUZÂKIN A. P., 1935: Novye dannye po sistematike i geografičeskomu rasprostraneniû letučih myšej (Chiroptera) v SSSR [New data on the systematics and geographical distribution of bats (Chiroptera) of the Soviet Union]. Bûlleten Moskovskogo Obŝestva Izpytatelej Prirody, Otdel Biologičeskij, N. S., 44: 428-438 (in Russian, with a summary in German).

KuzÂKın A. P., 1965. Otrâd Rukokrylye. Ordo Chiroptera [Order Bats. Ordo Chiroptera]. Pp.: 79-116. In: BobrinskiJ N. A., KuZnecov B. A. \& KuZÂKIn A. P. (eds.): Opredelitel mlekopitaûsih SSSR [Key to Identification of Mammals of the Soviet Union]. Prosveŝenie, Moskva, $384 \mathrm{pp}$ (in Russian).

LAY D. M., 1967: A study of the mammals of Iran resulting from the Street Expedition of 1962-63. Fieldiana: Zoology, 54: 1-282.

López-Baucells A., 2019: Geoffroy's Myotis Myotis emarginatus. Pp.: 950-951. In: Wilson D. E. \& Mittermeier R. A. (eds.): Handbook of the Mammals of the World. 9. Bats. Lynx Editions, Barcelona, $1008 \mathrm{pp}$.

MARGÓ T., 1880: Új denevérfajok a budapesti és magyarországi faunábán [New species of bats in the fauna of Budapest and Hungary]. Magyar Orvosok és Természetvizsgálók, 20: 252-256 (in Hungarian).

MAYER F., Dietz C. \& Kiefer A., 2007: Molecular species identification boosts bat diversity. Frontiers in Zoology, 4(4): 1-5.

Miller G. S., 1897: Revision of the North American bats of the family Vespertilionidæ. North American Fauna, 13: 7-129.

MiLler G. S., 1912: Catalogue of the Mammals of Western Europe (Europe Exclusive of Russia) in the Collection of the British Museum. Trustees of the British Museum, London, xv+1019 pp.

Morales A., Ruedi M., Field K. \& Carstens B. C., 2019: Diversification rates have no effect on the convergent evolution of foraging strategies in the most speciose genus of bats, Myotis. Evolution, 73: 2263-2280.

OgnefF S. I. \& Heptner W. G., 1928: Einige Mitteilungen über die Säugetiere des mittleren Kopet-Dag und der anliegenden Ebene (Russisch-Turkestan). Zoologischer Anzeiger, 75: 258-266.

OGNev S. I., 1927: A synopsis of the Russian bats. Journal of Mammalogy, 8: 140-157.

OGnev S. I., 1928: Zveri vostočnoj Evropy i severnoj Azii. Tom I [The Mammals of Eastern Europe and of Northern Asia. Volume I]. Gosudarstvennoe Izdatelstvo, Moskva \& Leningrad, 631 pp (in Russian).

Rossolimo O. L. \& Pavlinov I. Â., 1979: Katalog tipovyh èkzemplârov mlekopitaûŝih, hranâsihsâ v Zoologičeskom Muzee MGU [Catalogue of type specimens of mammals in the collection of the Zoological Museum of the Moscow State University]. Sbornik Trudov Zoologičeskogo Muzeâ MGU, 18: 5-43 (in Russian).

Ruedi, M., Stadelmann B., Gager Y., Douzery E. J. P., Francis C. M., Lin L.-K., Guillén-Servent A. \& Cibois A., 2013: Molecular phylogenetic reconstructions identify East Asia as the cradle for the evolution of the cosmopolitan genus Myotis (Mammalia, Chiroptera). Molecular Phylogenetics and Evolution, 69: 437-449. 
RYBIN S. N., HoRÁČEK I. \& ČERvenÝ J., 1989: Bats of southern Kirghizia: distribution and faunal status. Pp.: 421-441. In: HanáK V., HoráčEK I. \& GAISLER J. (eds.): European Bat Research 1987. Charles University Press, Praha, [xx]+718 pp.

SATUNIN K. A., 1896: Vorläufige Mittheilungen über die Säugethierfauna der Kaukasusländer. Zoologische Jahrbücher, Abtheilung für Systematik, 9: 277-314.

SATUNIN K. A., 1914: Opredelitel mlekopitaûsih Rossijskoj Imperii. Vypusk pervyj. (Rukokrylyâ, Nasekomoâdnyâ $i$ Hiŝnyâ) [Key of the Mammals of Russian Empire. First Volume. (Bats, Insectivores and Carnivores)]. Tiflis (in Russian).

Shahabi S., Sharifi M. \& Akmali V., 2019: Echolocation call frequency and mitochondrial control region variation in the closely related bat species of the genus Rhinolophus (Chiroptera: Rhinolophidae) occurring in Iran: implications for taxonomy and intraspecific phylogeny. Mammal Research, 64: 485-501.

Simmons N. B., 2005: Order Chiroptera. Pp.: 312-529. In: Wilson D. E. \& Reeder D. M. (eds.): Mammal Species of the World. A Taxonomic and Geographic Reference. Third Edition. Volume 1. The Johns Hopkins University Press, Baltimore, xxxviii+743 pp.

Stadelmann B., Jacobs D. S., Schoeman C. \& Ruedi M., 2004: Phylogeny of African Myotis bats (Chiroptera, Vespertilionidae) inferred from cytochrome $b$ sequences. Acta Chiropterologica, 6: 177-192.

Strelkov P. P., 1963: II. Otrâd Chiroptera - Rukokrylye [II. Order Chiroptera - bats]. Pp.: 122-218: In: Sokolov I. I. (ed.): Mlekopitâिsie fauny SSSR. Cast 1 [Mammals of the Fauna of the Soviet Union. Part 1]. Izdatelstvo Akademii Nauk SSSR, Moskva \& Leningrad, 640 pp (in Russian).

STRELKov P. P., 1972: Ostrouhie nočnicy; rasprostranenie, geografičeskaâ izmenčivost', otličiâ ot bol'ših nočnic [Lesser mouse-eared bats; distribution, geographical variation, differences from the greater mouse-eared bats]. Acta Theriologica, 17: 355-380 (in Russian, with an abstract in English).

Strelkov P. P., 1981: Otrâd Chiroptera Blumenbach, 1779 - Rukokrylye [Order Chiroptera Blumenbach, 1779 - Bats]. Pp.: 31-53. In: Gromov I. M. \& Baranova G. I. (eds.): Katalog mlekopitaûsih SSSR. Pliocen-Sovremennost [Catalogue of Mammals of the Soviet Union. Pliocene-Recent]. Nauka, Leningrad, 456 pp (in Russian).

Strelkov P. P., Sosnovceva V. P. \& Babaev N. V., 1978: Letučie myši (Chiroptera) Turkmenii [The bats of Turkmenistan]. Trudy Zoologičeskogo Instituta Akademii Nauk SSSR, 79: 3-71 (in Russian, with a subtitle in English).

Thomas O., 1920: Scientific Results from the Mammal Survey. No. XXI. A. - Some new mammals from Baluchistan and North-West India. Journal of the Bombay Natural History Society, 26: 933-938.

TopÁL G., 1971: The taxonomic position of Myotis dobsoni (Trouessart, 1879), and some statistical data to the subspecific examination of Myotis blythi (Tomes, 1857). Annales Historico-naturales Musei Nationalis Hungarici, Pars Zoologica, 63: 383-400.

TopáL G., 2001: Myotis emarginatus (Geoffroy, 1806) - Wimperfledermaus. Pp.: 369-404. In: KraPP F. (ed.): Handbuch der Säugetiere Europas. Band 4: Fledertiere. Teil I: Chiroptera I. Rhinolophidae, Vespertilionidae 1. Aula-Verlag, Wiebelsheim, $\mathrm{x}+603 \mathrm{pp}$.

UvizL M. \& BENDA P., 2021a: Intraspecific variation of Myotis emarginatus (Chiroptera: Vespertilionidae) inferred from mitochondrial and nuclear genetic markers. Acta Chiropterologica, 23: 285-300.

Uvizl M. \& Benda P., 2021b: Diversity and distribution of the Myotis nattereri complex (Chiroptera: Vespertilionidae) in the Middle East: filling the gaps. Mammalian Biology, 101: 963-967.

Wroughton R. C., 1920: Bombay Natural History Society's Mammal Survey of India, Burma, and Ceylon. Report No. 32, Baluchistan. Journal of the Bombay Natural History Society, 27: 314-322.

\section{APPENDIX}

List of specimens examined

Afghanistan: 2 + (SMF 38916, 38917 [S+A]), Kabul, 18 July 1962, 8 May 1963, leg. D. MeYer-Oehme. Albania: 1 q (NMP 96605 [S+A]), Fshat, 1 July 2018, leg. P. BeNDA; - 1 q (NMP 96497 [S+A]), Gjirokastër Castle, 2 July 2015, leg. P. Benda, F. Spitzenderger, M. Uhrin \& E. Weiss; - 2 + $q$ (NMP 
96501, 96502 [S+A]), Krongj, Vris Stream, 3 July 2015, leg. P. Benda, F. Spitzenberger, M. Uhrin \& E. Weiss; - 1 ô (NMP 96524 [S+A]), Selcë, Selcë River, 8 July 2015, leg. P. Benda, F. Spitzenberger, M. Uhrin \& E. WeIsS.

Algeria: 5 우우 (MUB A050, 243, 244, 246, VMO 4717 [S+B]), Bejaïa, Aokas, 21 May 1981, 14 May 1982, leg. J. GAISLER; - 1 9 (ISEA 9617 [S+B]), Madagh, 10 April 1982, leg. K. KowalsKi \& B. RzEBIK-KowALSKa; - 3 ôे $\widehat{\jmath}, 1$ q, 1 ind. (ISEA 9606, 9614-9616, 9618 [S+B]), Sig, 21 December 1978, 2 and 30 July 1979, 29 October 1979, 4 December 1982, leg. K. KowalsKi \& B. RzebiK-KowalsKa.

Austria: 1 đ (NMW 51071 [S+B]), Bad Fischau-Brunn, Niederösterreich, 23 January 1993, leg. E. BAAR; -1 ઈิ (NMW 29424 [S+B]), Drachenhöhle Cave, Steiermark, 4 January 1976, leg. A. MAYER; - 1 \& (NMW 30430 [S+B]), Eggenburg, Niederösterreich, 19 March 1979, leg. H. J. LAuermanN; - 1 q (NMW 29988 [S+A]), Göttlesbrunn, Niederösterreich, 1905, leg. SCHLERETH; - 1 o (NMW 51073 [S]), Hohenau an der Raab, Steiermark, 14 March 1993, leg. H. PoLT; - 4 우 (NMW 9117-9119 [S+B], 9158 [S]), Kaltenleutgeben, Wien 25, 19 June 1955, 27 May 1963, leg. J. Vornatscher \& K. BAuER; - 5 ồ $\hat{\jmath}, 2$ 우 (NMW 19982, 51072, 51152, 51426, 52209 [S+B], 36982, 51427 [S]), Kirchberg am Wechsel, Niederösterreich, 26 May 1965, 6 August 1975, 16 March 1985, 15 March 1986, 21 May 1993, 27 July 1994 \& 12 August 1994, leg. A. MAYER \& B. FreitaG; - 1 đ̂ (NMW 12030 [S+B]), Kleinzell, Lilienfeld, Niederösterreich, 4 December 1966, leg. H. HaRTMAnN; - 1 ภ (NMW 30431 [S+B]), Laab im Walde, Niederösterreich, 23 June 1979, leg. A. MAYER; - 2 우 (NMW 52322, 53498 [S]), Laussa, Oberösterreich, 27 July 1991, 3 August 1996, leg. J. Blumenschein \& E. Weiss; - 1 (NMW B4794 [S]), Laxenburg, Niederösterreich, 20 August 1930, collector unlisted; - 1 ô (NMW 52323 [S]), Naas, Steiermark, 7 January 1996, leg. A. MAYER; - 1 क (NMW 15709 [S+B]), Peggau, Graz-Umgebung, Steiermark, 20 January 1973, leg. A. MAYER; -1 q (NMW 53496 [S]), Pöttsching, Mattersburg, Burgenland, 14 July 1988, leg. A. BAAR; - 1 § (NMW 29425 [S+B]), Pyhra, Niederösterreich, 25 June 1977, leg. O. Moog; - 1 क (NMW 30432 [S+B]), Scheiblingkirchen-Thernberg, Niederösterreich, 16 May 1981, leg. H. RASCH.

Azerbaijan: 1 đ̊ (NMP 91691 [S+B]), Boyuk Taglar, 26 September 1967, leg. I. Rahmatulina; - 12 q 9 (NMP 91395, 91397-91404 [S+A], 91396 [A], 91393, 91394 [S+B]), Mingəçevir, 25-26 June 1984, leg. V. HANÁK; - 2 우 (ZIN 77341, 77342 [S+B]), Lenkoran', čajnaâ fabrika No. 1, 10 July 1984, leg. I. RAHMATULINA.

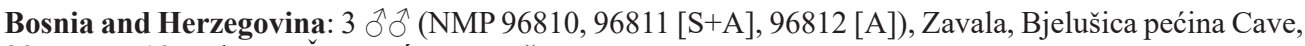
29 August 1977, leg. J. ČERVENÝ \& J. KuČERA.

Bulgaria: 7 ๙ึ (NMP 38560, 38561, 38563, 47/72C, 47/72F, 47/72G, 47/72I [S+B]), Âgodina, 2 August 1971, leg. J. ČervenÝ, I. HorÁČEK, A. TAušL \& D. VíteK; - 3 ổ (NMP 50317-50319 [S+A]), Âgodina, Imamova dupka Cave, 15 August 1978, leg. P. Donát, J. Flegr, J. JANDA \& V. Vohralík; - 3 $\lesssim$ (NMP 50314-50316 [S+A]), Âgodina, Sančeva dupka Cave, 15 August 1978, leg. P. Donát, J. Flegr, J. JANDA \& V. Vohralík; - 9 qO (NMP 50360-50368 [A]), Arkutino, 13 May 1983, leg. D. Král \& D. Scholz; - 1 ô (NMP 38562 [S+B]), Gela, 31 July 1971, leg. J. ČERvenÝ, I. HorÁČEK, A. TAuŠL \& D. VíteK; - 5 inds. (NMP 50326-50330 [S+A]), Golâm Kamăk, 13 July 1979, leg. D. HoleČKová, P. Donát, I. HoráČEK, J. Jirouš \& V. VohralíK; - 1 ô, 6 우 (NMP 50222, 50231-50233 [S+A], 50207, 50223, 50303 [A]), Karlukovo, 3 July 1976, 12 June \& 4 June 1977, 9 August 1978, leg. V. BEJČEK, M. Braniš, P. Donát, J. Flegr, V. Hanák, I. HoráčeK, K. HŮrka, J. JANDA, J. Jirouš, J. ŠKopeK, V. Švihla, P. VašÁK \& V. Vohralík; - 1 q (NMP 50325 [S+A]), Komunari, 12 July 1979, leg. D. HolečKová, P. Donát, I. Horáček, J. Jirouš \& V. Vohralík; - 6 ō ổ (NMP 50339-50344 [S+A]), Orehovo, 30 August 1980, leg. D. HolečKová, J. Jirouš, H. Prágerová \& V. Vohralík; - 2 q (NMP 50205 [S+A], IVB 11/35 [S+B]), Peŝera, Snežânka Cave, 19 September 1962, leg. J. GaISLER; - 1 q (IVB 38/1603 [S+B]), Peŝera, Ušatovi dupki, 8 August 1967, leg. J. GaisLer; - 1 q (NMP 47/72/C96 [S+B]), Primorsko, 17 August 1971, leg. J. ĆERVENÝ, I. HoRÁČEK, A. TAUŠL \& D. VÍTEK; - 31 q (NMP 49147, 49149, 49153-49161, 49163, 49164 [S+B], 50183-50190, 50192-50197 [S+A], 50278, 50281, 50285, 50286 [A]), Sliven, Zmeevi dupki Cave, 25 May 1957, 15 July 1975, leg. V. HanÁK \& J. ČervenÝ; - 2 đે ồ (NMP 50150, 50151 [S+B]), Velingrad, Lepenica peŝera Cave, 9 July 1981, leg. J. Flousek, R. Fuchs \& V. Vohralík. 
Croatia: 1 đ, 1 (ZZZ 3056, 3057 [S+B]), Korčula, Postrana, 29 July 1969, leg. B. Đulić; - 2 q $q$ (ZZZ 3052, 3053 [S+B]), Pupnat, Korčula, 28 July 1969, leg. B. Đulić; - 1 q (ZZZ 3076 [S+B]), Vis, 30 July 1969, leg. B. Đulić; - 2 đ̂̉, 2 우 (ZZZ 307, 344, 349, 350 [S]), Zagreb, Veternica Cave, date \& collector unlisted; - 1 +, 3 inds. (ZZZ 352, 3102, 10568, 10571 [S]), Croatia, site, date \& collector unlisted.

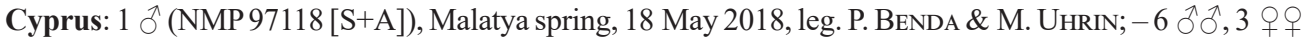
(NMP 90400, 90401, 90931-90935, 91264 [S+A], 90936 [A]), Troodos Forest, 4.5 km SW of Kakopetria, 29 March, 11 April \& 13 October 2005, 27 July 2006, leg. P. Benda, I. HoráčeK, P. Hulva \& R. LuČan.

Czech Republic: 1 (NMP 24/69 [S+B]), Dobrošov, 20 March 1969, leg. M. ANDĚRA \& P. ZBYTOvSKÝ; - 2 오우 (NMP 58/59, 61/59 [S]), Javoříčko, Javoříčské jeskyně Cave, 27 January 1959, leg. V. HANÁK; - 15 우 우 (NMP 831/59, 833/59, 834/59, 836/59, 837/59, 157/62, 158/62, 161/62-163/62 [S+B], 832/59, 835/59, 841/59, 159/62, 160/62 [S]), Jevišovice, 24 July 1959, 14 June 1962, leg. V. HANÁK \& K. HŮRKA; - 1 q (NMP 127/62 [S+B]), Karlštejn, Gaislerova štola Mine, 23 March 1962, leg. V. Hanák; - 14 우, 2 inds. (NMP 194/65, 195/65 [S+B], 183/65-193/65, 197/65, 200/65, 201/65 [S]), Lednice, 13 June 1965, leg. V. HanÁk; - 1 Õ, 1 q (NMP 119/63 [S+B], 120/63 [B]), Mikulov, Na Turoldě Cave, 4 March 1963, leg. J. GaISLER \& V. HANÁK; - 1 ô (NMP 350/58 [S]), Mníšek pod Brdy, 8 March 1958, leg. J. SkLenář;-

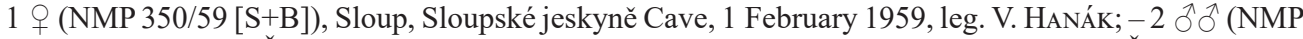
228/59, 229/59 [S]), Šternberk, 30 January 1959, leg. V. HANÁk; - 1 + (NMP v12151 [S]), Šumperk, date \& collector unlisted; - 1 đ̊ (NMP 24B/61 [S]), Velehrad, 10 February 1961, leg. V. HaNÁK; - 1 ô (NMP zn22 [S]), Vranov nad Dyjí, 31 July 1957, leg. V. HaNák.

France: 1 (ZFMK 97.110 [S+B]), Aigues-Mortes, Gard d'France, 27 June 1958, leg. C. KöNIG; -

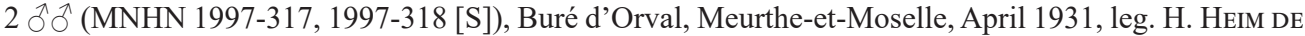
BALSAC; - 1 ㄱ, 3 오오 (MNHN 1963-865, 1963-866, 1984-89, 1984-90 [S+A]), Cachan, Val-de-Marne, 31 March 1946, 26 January 1947, 31 March 1948, leg. J. BAlazuC \& J. DE BAufFremont; - 1 + (SMF 19365 [S+B]), Cap Corse, Brando, Corsica, 27 September 1953, leg. H. KahmanN; - 1 ind. (MNHN 1997-1947 [B]; paratype of Vespertilio emarginatus Geoffroy, 1806), Charlemont, date unlisted, leg. Colonel Geofrroy; - 3 우 (SMF 19171-19173 [S+B]), Les Baux, Grotte des Fées Cave, Bouches-du-Rhone, 20 June 1958, leg. C. KöNIG; - 2 우 (MNHN 1998-955, 1998-956 [S+B]), Les Riceys, Grotte de Frolle Cave, Aube, 13 March 1981, leg. J. Cuisin; - 1 đ (MNHN 1963-868 [S+B]), Mériel, Setoise, 9 February 1947, leg. J. Balazuc; - 1 구, 2 우우 (MNHN 1984-116-1984-118 [S+A]), Mortagne, Orne, date \& collector unlisted; - 1 + (SMF 50429 [S+B]), Rapale, Corsica, 28 August 1976, leg. H. E. BACK; - 1 ( (SMF 19366 [S+B]), Sorio, Corsica, 3 July 1956, leg. H. Kahmann; - 1 ( [S+A]), Tourtenay, Deux-Sèvres, 23 December 1951, leg. F. ChanudeT; - 1 q (MNHN 1963-867 [S+A]), Varreddes, Seine-et-Marne, 13 February 1944, leg. J. BALAZuc.

Georgia: 7 우 (NMP 91528, 91536, 91541, 91547, 91550-91552 [S+B]), Džal, 14 July 1964, leg.

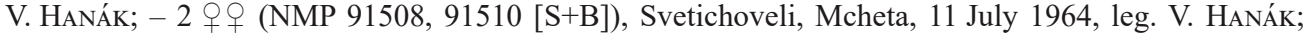
-2 우 (ZMMU S84000, S84001 [S+B]), Georgia (undef.), 29 and 31 August 1939, leg. A. KuZÂKIn.

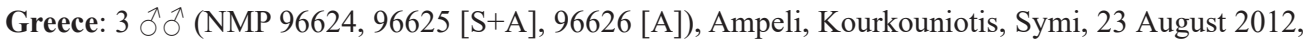
leg. P. BENDA; - 29 우 (NMW 31360-31369, 31371-31373, 31376, 31378, 31379, 31382 [S+A], 31370, 31374, 31375, 31377, 31380, 31381, 31383-31386 [S+B], 31359 [S]), Fledermaushöhle Cave, Petralona, 3 June 1977, leg. J. WirTH; - 2 ồ (NMW 35454, 35455 [S+B]), Korykische Grotte (Sarandavli Tropfsteinhöhle) Cave, ESE of Delphi, 7 August 1979, leg. A. BAAR \& W. BAAR; - 8 우 (NMW 45753-45760 [S+A]), Bunker-Stollen an Abzweigung Stavros an Straße Rendina-Asprovalta, 12 July 1979, leg. U. Passauer; - 1 o (NMP 48630 [S+B]), Xanthi, Kosynthos River, 17 June 1989, leg. R. ChaloupKa, V. HANÁK \& V. VOHRALÍK.

Iran: 1 (NMP 90856 [S+A]), Ali Abad, 28 June 2006, leg. P. BENDA \& A. ReITER; - 1 ô (BMNH 77.828 [S+B]), Azad-Khan Cave, Mahallet, date unlisted, leg. E. ETEMAD; - 1 ind. (JOC unnumbered [Sk]), Bazangan, 8 October 2002, leg. J. ОвUCH; - 1 (NMP 90765 [S+A]), Emamzadeh Mousa, Razmiyan, 12 May 2006, leg. P. Benda \& A. Reiter; - 1 क (NMP 48448 [S+A]), Gishan, Bandar Abbas, 19 April

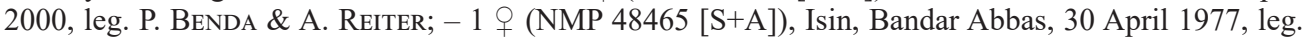


B. PraŽAN; - 1 q, 3 inds. (BMNH 9.1.4.33, 74.11.21.29, 74.11.21.30 [S], MSNG 44541 [A]; incl. the syntype series of Vespertilio desertorum Dobson, 1875), Jalk, Baluchestan, date unlisted, leg. Royal Army Medical College \& W. J. Blanford; - 1 q (NMP 90884 [S+A]), Pul, Chalus, 1 June 2006, leg. P. Benda \& A. ReITER; - 1 (NMP 94106 [S+Sk]), Qutur Su, 29 September 2011, leg. M. ANDREAS, P. Benda, A. REITER \& M. Uhrin.

Israel: 1 (TAU M6570 [S+B]), Hazorea, 14 April 1975, leg. D. MAKIN; - 6 + $\circ, 3$ inds. (NMW 33850, TAU M2474-M2476, M2481, M6547, M6864, M6865 [S+B], TAU M2858 [S]), Nahal Oren, Etsba Cave, Mt. Carmel, 24 April 1960, 6 May 1962, 14 April 1975, 5 April 1976, leg. D. Harrison \& D. MaKin; 1 đิ (TAU M6373 [S+B]), Maagan Mikhael, 10 June 1974, leg. D. MaKIn.

Italy: 8 우 (SMF 17165-17167, 17173-17177 [S+A]), Lingulaglossa, Grotta Corruccio Cave, Catania, Sicilia, 10 July 1955, leg. K. Klemmer \& H. E. Krampitz; - 1 ठ (SMF 10836 [S+A]), Sassari, Grotta del Inferno Cave, Sardinia, 22 March 1951, leg. H. Felten, Frich \& Müller.

Jordan: 1 (NMP 92523 [S+A]), Arjan, 25 May 2009, leg. P. BendA \& A. Reiter; - 4 + 9 (NMP 92554-92557 [S+A]), Kufranja, Iraq Al Wahaj Cave, 26 May 2009, leg. P. Benda \& A. ReITER; - 3 q 9 (NMP 92520, 92521 [S+A], 92522 [A]), Zubiya, Zubiya Cave, 24 May 2009, leg. P. BendA \& A. Reiter.

Kazakhstan: 12 + (ZIN 62160-62171 [S+A]), Eastern slopes of the Karatau Mts., ur. Altyntau, Suzakskij Dist., 2 July 1975, leg. P. Strelkov; - 1 + (ZMMU S83999 [S+B]), Kazakhstan (undef.), 10 June 1944, leg. O. Bogdanov.

Kirghizstan: 1 + (SMF 77779 [S+A]), Sasik Ungur, 30 May 1990, leg. J. ČERvenÝ.

Lebanon: 2 q (NMP 93554, 93555 [S+A]), Aanjar Cave, 5 June 2010, leg. P. BendA \& M. Uhrin; - 1 (NMP 91893 [S+A]), Afqa Cave, 17 January 2008, leg. P. BENDA, I. HorÁČEK, R. LuČAn \& M. Uhrin; - 2 ถึ $\widehat{~}$ (NMP 93574, 93575 [S+A]), El Jaouz Cave, Khirbet Qanafar, 9 June 2010, leg. P. BENDA

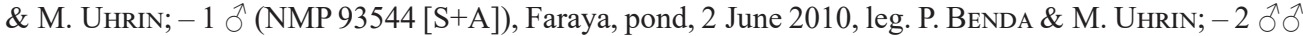
(NMP 93540, 93541 [S+A]), Faraya, Raymond Cave, 2 June 2010, leg. P. Benda \& M. Uhrin; - 2 §ิ ô (NMP 95793, 95794 [S+A]), Jezzine, Pont El Khalass, 23 June 2006, leg. I. HoráČEK, P. Hulva, R. LuČAN \& P. NĚMeC; - 2 ภิ (NMP 93562 [S+A], 93563 [A]), Majdal Tarshish, Qattine Aazar Chasm, 7 June 2010, leg. P. Benda \& M. Uhrin; - 1 o (NMP 91758 [S+A]), Marjaba, mine, 19 January 2007, leg. P. BENDA, R. ČERNÝ, I. HORÁČEK \& R. LUČAN.

Montenegro: 2 $\widehat{\jmath}, 2$ 우 (NMP 90213-90216 [S+A]), Rijeka Crnojevića, Rijeka Crnojevića River, 1 August 2002, leg. P. BendA; - 1 ô, 1 + (NMP 90206, 90207 [S+A]), Risan, Sopot Cave, 31 July 2002, leg. P. BENDA.

Morocco: 1 ( (MHNG 1492.87 [S]), 145 km ENE of Marrakech, Grotte du Caïd Cave, Aïd Mehommed, 5 June 1978, leg. P. StRINATI; - 1 o (MNHN 1985-1564 [S+A]), Berkane, Grotte de Tazarine Cave, 1955, leg. A. Brosset; - 2 우 (ZFMK 61.217, 61.218 [S+B]), Taforalt, 30 April 1961, leg. H. Roer.

Oman: 1 \& (NMP 93772 [S+A]), Al Hoota Cave, 8 April 2011, leg. P. BendA, A. Reiter \& M. Uhrin; - 1 ð (NMP 93819 [S+A]), Al Khudhayrah, 10 April 2011, leg. P. Benda, A. Reiter \& M. Uhrin; - 1 ठ (NMP 93788 [S+A]), Misfah, 9 April 2011, leg. P. Benda, A. Reiter \& M. Uhrin; - 1 ðे (NMP 93996 [S+A]), Sal Alah, Birkat Khaldiyah, 13 March 2012, leg. P. BendA, A. Reiter \& M. Uhrin; - 2 우 (NMP 93753 [S+A], 93754 [A]), Sawt, 6 April 2011, leg. P. BendA, A. Reiter \& M. Uhrin; - 1 q (NMP 93794 [S+A]), Tanuf, Ain Ghubrat Cave, 10 April 2011, leg. P. BendA, A. Reiter \& M. Uhrin; - 1 q (NMP 93735 [S+A]), Tayma, 3 April 2011, leg. P. Benda, A. Reiter \& M. Uhrin.

Portugal: 1 q (SMF 18066 [S+A]), Coimbra, Bordalao, 13 July 1928, leg. M. M. DA GAMA.

Russia: 1 đ (ZMMU S21535 [S+B]), Kavkazskij zapovednik Reserve, Majkopskij Dist., 27 August 1932, collector unlisted.

Serbia: 8 우, 1 ind. (ZIN 35058-35061, 35422, 48086, ZMMU S43760, S43761 [S+B], NMW 9367 [S]), Beograd, Topčider, 31 May 1936, 11 May, 15 May and 24 May 1942, 6 June 1946, 15 August 1949, leg. V. Martino, E. Martino, Ž. Adamovič \& A. Petrova. 
Slovakia: 1 đิ (NMP 24/61 [B]), Drienovec, Drienovecká jaskyňa Cave, 18 February, 1961, leg. V. HANÁk;

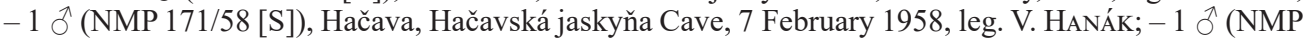
14/74 [S+B]), Haligovce, Aksamitka Cave, 28 July 1972, leg. I. HorÁčEK; - 1 ô (NMP j4 [S]), Jihoslovenský kras [Slovakian Karst Mts.], 6-12 December 1956, leg. V. HANÁK.

Spain: 1 đ (EBD 15538 [S+B]), Casa Dos Guejigales, Ronda, Málaga, Sra. de las Wieres, 19 June 1987, collector unlisted; - 1 ô (SMF 21481 [S+B]), Linares de Riofrio, Salamanca, 30 August 1962, leg. H. GRÜNN; - 1 ठૈ, 1 † (EBD 9925, 9926 [S+B]), Cueva del-Negro Cave, Monte Carbonal, Huétor de Santillán, Granada, 21 August 1963, collector unlisted; - 1 ô (EBD 9927 [S+B]), Palacio de Doñana, Huelva, 27 July 1966, collector unlisted; - 5 우 (EBD 9606, 9684, 9686, 9701, 9707 [S]), Pantano de los Bermejales, 4 June \& 26 July 1983, collector unlisted; - 1 ò (EBD 15428 [S+B]), Perezoso de Camilla, $4 \mathrm{~km} \mathrm{~N}$ of Lisero de la Hana del Ravel, 4 July 1987, collector unlisted.

Syria: 1 q, 1 ind. (TAU M8427, M9440 [S+B]), Mount Hermon, 27 April 1988, 20 June 1995, leg. E. Erez, D. Makin \& B. Shalmon; - 16 inds. (NMP 90326-90341 [S]), Qala' at Salah Ad Din, 13 October 2004, leg. R. LuČAn; - 8 우 (NMP 48939-48946 [S+A]), Qala'at Samaan, 3 June 2001, M. ANDrEAS, A. Reiter \& D. Weinfurtová; - 1 q (NMP 47927 [S+A]), Ras Al Bassit, 18 May 1995, leg. P. Benda.

Switzerland: 1 đ (MHNG 967.95 [S]), Doubs, Grotte du Moron Cave, 16 November 1946, leg. V. AELEN.

Tajikistan: 1 đ (NMP 95754 [S+A]), Kalkot, Ar Arak Cave, 17 May 2016, leg. P. Benda, A. Reiter \& M. Uhrin; - 1 o (NMP 95724 [S+A]), Kulob, 6 May 2016, leg. P. BendA, A. Reiter \& M. Uhrin; - 15 우우 (NMP 95714-95719, pb6164-pb6170 [S+A], 95720, pb6178 [A]), Levap, 5 May 2016, leg. P. Benda, A. Reiter \& M. Uhrin; - 1 क, 1 ind. (ZMMU S94708, S94709 [S+B]), meždu k. Majkata i Amandara, 20 July 1959, leg. O. Bogdanov.

Turkey: 9 우 (NMP 47932, 47935-47939, 47941-47943 [S+A]), Çevlik, 20 May 1995, leg. P. BendA, J. ČrHÁKová \& J. FlegR; - 8 우 (NMW 13419, 13423, 13426-13431 [S+A]), Höhle S Kiyiköy (= Midye), Kirklareli, 2-3 June 1968, leg. K. Bauer \& F. SPitzenberger; - 1 ô (NMW 34373 [S+B]), Olimpos, Antalya, 31 July 1984, leg. F. Spitzenberger; - 1 ô (NMP 47959 [S+B]), Safe suyu Cave, 1 September 1996, leg. M. Andreas, P. Benda \& M. Uhrin; - 1 ô (NMP T93/33 [S+A]), Sarpdere, Dupnisa Cave, 16 October 1993, P. BENDA \& I. HoRÁČEK; - 1 ind. (ZMH 2836/S9185 [S+B]), Tarsus Adana, date unlisted, leg. K. LeOnhardT; - 1 † (NMW 11815 [S+B]), Burgruine 4 km SE Yalova, Canakkale, 31 May 1967, leg. K. Bauer, F. SPitzenberger, M. Ganso \& L. Wald.

Turkmenistan: 3 우 (ZIN 54176, 56666, 59541 [S+B]), Bahardenskaâ peŝera Cave, 12 May 1965, 12 May 1967, 12 June 1970, leg. H. Babaev \& P. Strelkov; - 2 우 (ZIN 54195, 57944 [S+B]), Svincovyj Rudnik, Kučitan'-Tau Mts., 31 May 1967, 18 May 1971, leg. P. Strelkov; - 1 đ̄ (ZMMU S104386 [S+A]; holotype of Myotis emarginatus turcomanicus Bobrinskoj, 1925), Turkmen Kala, Murgab Valley, 11 June 1917, leg. S. T. BIL'KeVIČ; - 1 ind. (ZMMU S29213 [S+B]), Verhne-Skobelevskij, Ašhabadskij Dist., 6 June 1925, leg. S. OGNev.

Ukraine, Crimea: 5 우 우 (ZIN 43963-43967 [S+A]), Buhta-Barahta, Karadag, 1 August 1960, leg. N. Filipova \& A. Popov; - 1 q (ZIN 44054 [S+B]), Karadag, 6 June 1960, leg. Dmitrieva; - 3 q + (ZIN 29329, 29330, ZMMU S28574 [S+B]), Karasu-Baši, 25 June 1938, leg. B. Popov; - 1 q (ZIN 54335 [S+B]), Simferopol', June 1967, leg. P. Strelkov \& A. Konstantinov.

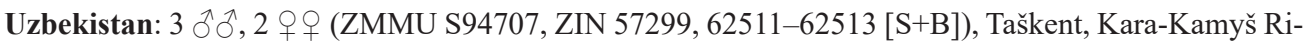
ver, 15 May \& 27 June 1946, 22 July 1953, leg. A. ANDRUŠKo \& O. BogdanOv; -7 q 9,1 ind. (ZMMU S6818, S29234-S29236, S94117, S94710, ZIN 57300, 59441 [S+B]; including the holotype of Myotis lanaceus saturatus Kuzâkin, 1934), Taškent, 15 June 1932, 7 July 1947, 8 May 1949, leg. R. MekLENBURCEV, O. BOGDaNOV \& S. Ognev. 